\title{
Clinical-epidemiological studies on cutaneous
} malignant melanoma

- A register approach

\author{
Johan Lyth
}

\section{Linköping University \\ FACULTY OF HEALTH SCIENCES}

Linköping University, Faculty of Health Sciences

Department of Clinical and Experimental Medicine,

Division of Clinical Sciences, Oncology

SE-581 85 Linköping, Sweden

Linköping 2015 
CJohan Lyth, 2015

All previously published papers were reproduced with permission from the publisher.

Printed in Sweden by LIU-Tryck, Linköping, Sweden, 2015

ISBN: 978-91-7519-191-1

ISSN: 0345-0082 
TILL IDA, SIGRID OCH ALVA 



\section{Contents}

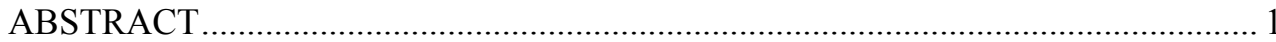

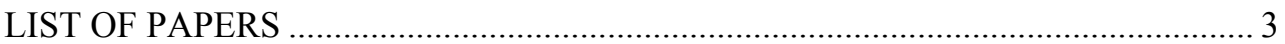

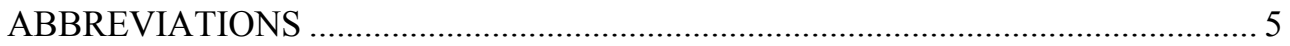

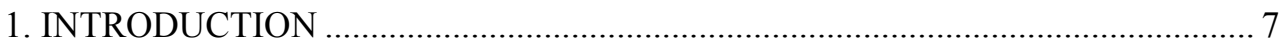

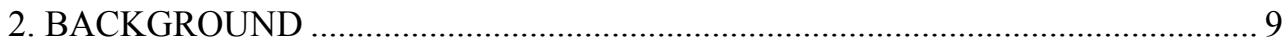

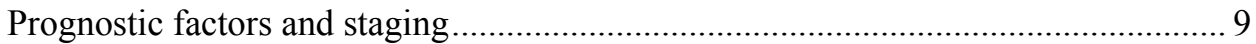

Swedish melanoma study group (SMSG) and Swedish melanoma register (SMR). 11

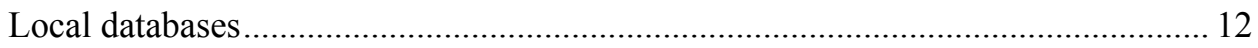

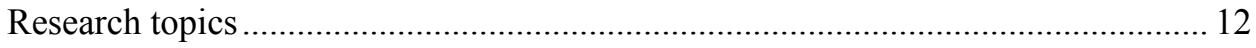

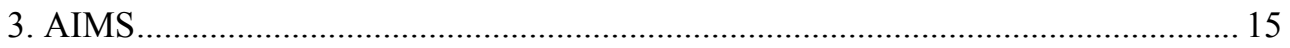

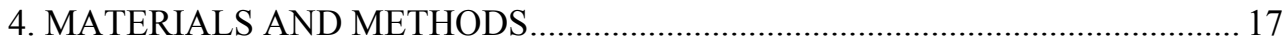

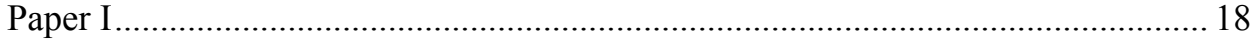

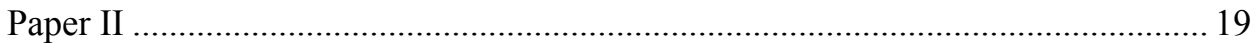

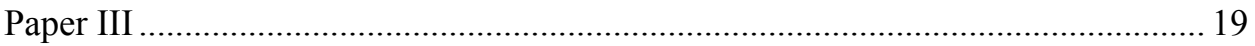

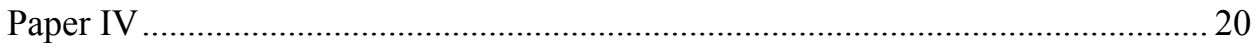

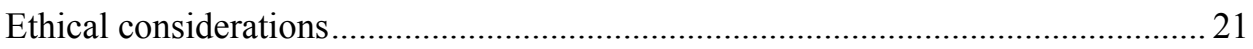

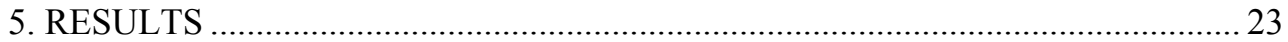

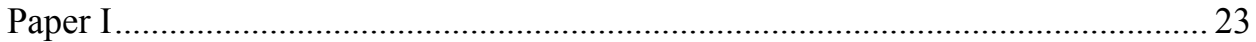

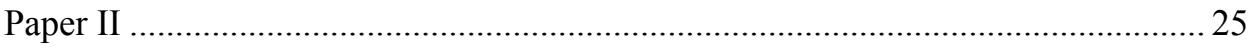

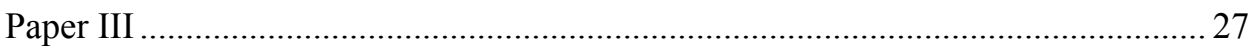

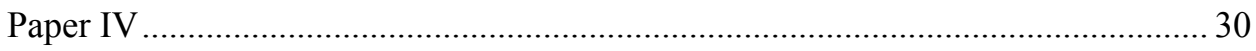

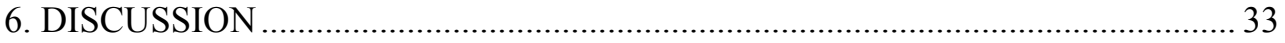




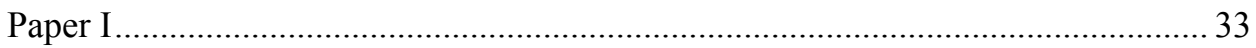

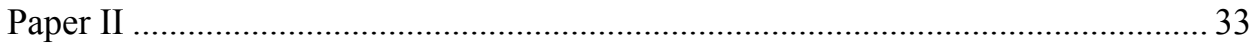

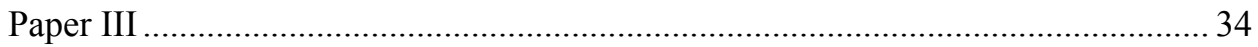

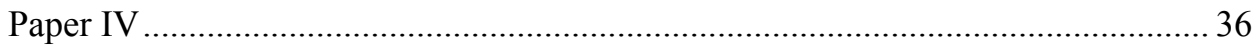

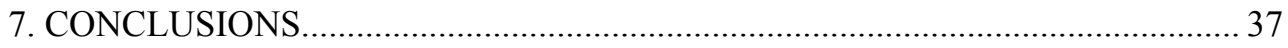

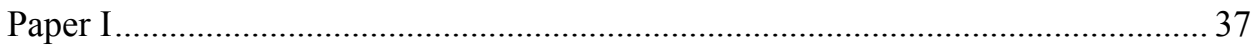

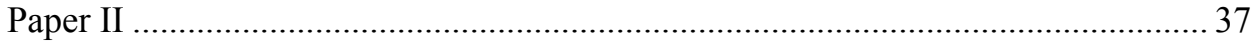

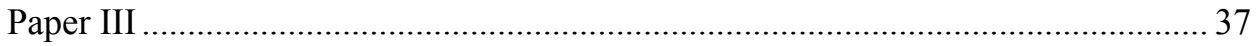

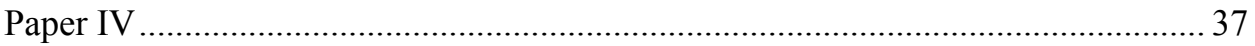

8. IMPLICATIONS AND FUTURE PERSPECTIVES …………………………......... 39

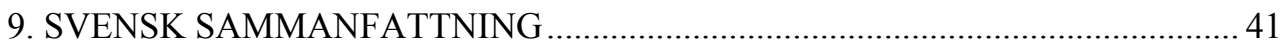

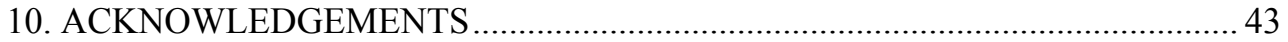

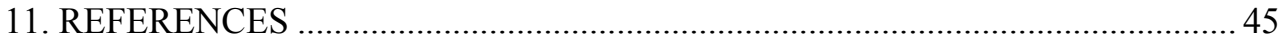




\begin{abstract}
Background The incidence of cutaneous malignant melanoma (CMM) is steadily increasing. Most of the patients have thin CMM with a good prognosis and a 5-year survival of about $90 \%$. The prognosis is highly related to tumour thickness and clinical stage at diagnosis. Effective systemic treatment for patients with metastatic disease has only recently been available. This thesis aims to increase knowledge of trends in tumour thickness, prognostic factors, socioeconomic differences and medical costs in patients with CMM.
\end{abstract}

Material and methods The population-based Swedish melanoma register is the main source of data in all papers in the thesis. Papers I-III include patients from all of Sweden while paper IV is delimited to the County of Östergötland. Cox regression and logistic regression are the main multivariable methods used. Paper IV is focused on stage-specific costs of CMM by comparing direct healthcare costs to a general population.

Results The odds ratio for being diagnosed with thicker tumours was significantly reduced and the CMM-specific survival significantly improved in men diagnosed 2007-2011 compared to men diagnosed 1997-2001 (hazard ratio=0.81; 95\% CI=0.720.91) while the corresponding differences for women were not significant. Ulceration, tumour thickness and Clark's level of invasion all showed significant independent long-term prognostic information among T1 CMMs. By combining these factors the patients could be subdivided into three risk groups with a 10-year CMM-specific mortality of $1.5 \%, 6.1 \%$ and $15.6 \%$, respectively. The odds ratio of higher disease stage at diagnosis was significantly increased in patients with low education versus patients with high education (odds ratio stage II vs $\mathrm{I}=1.6 ; 95 \% \mathrm{CI}=1.5-1.7$, odds ratio stage III-IV vs $\mathrm{I}=2.3 ; 95 \% \mathrm{CI}=1.8-2.9)$. The unadjusted risk of dying from CMM was twice as high in patients with low education versus patients with high education (hazard ratio $=2.02 ; 95 \% \mathrm{CI}=1.80-2.26$ ). Adjusting for sex, age and clinical stage at diagnosis decreased the risk to $19 \%$ in these patients (hazard ratio $=1.19 ; 95 \%$ $\mathrm{CI}=1.06-1.34)$. The first year after CMM diagnosis, the average health care costs for 
CMM patients was 2.8 times higher than in the general population. The CMM-related costs per patient-year varied from $€ 2670$ (stage I) to $€ 29291$ (stage IV). During the first year after diagnosis, patients in clinical stage III-IV (7\% of CMM patients) accounted for $27 \%$ of the total CMM-related healthcare costs.

Conclusions For men, there has been a shift over time towards thinner tumours at diagnosis accompanied by an improved survival. Women are still diagnosed with considerably thinner tumours and they experience a better survival than men. Tumour ulceration, tumour thickness and Clark's level of invasion all showed significant independent long-term prognostic information in T1 CMMs. By combining these factors, three distinct prognostic subgroups were identified. Lower level of education was associated with reduced CMM-specific survival, which may at least partially be attributed to a more advanced stage at diagnosis. The direct healthcare costs for CMM patients were significantly higher than for the general population, independent of clinical stage. CMM patients diagnosed in clinical stage III-IV were associated with particularly high costs.

Implications Even though the survival among Swedish patients with CMM is among the highest in the world and still seems to improve, the results of this thesis emphasise the need of improved early detection strategies. This may be of particular concern in men, older women, and groups with a low level of education. The results also imply that the costs for the management of CMM patients may be reduced if early detection efforts are successful and lead to a more favourable stage distribution. The finding of a better risk stratification of thin CMMs may help to improve the management of this large patient group. 


\section{LIST OF PAPERS}

This thesis is based on the following original papers, which will be referred to in the text by their Roman numerals:

I: Lyth J, Eriksson H, Hansson J, Ingvar C, Jansson M, Lapins J, Månsson-Brahme E, Naredi P, Stierner U, Ullenhag G, Carstensen J, Lindholm C. Trends in cutaneous malignant melanoma in Sweden 1997-2011: Thinner tumours and improved survival among men. Br J Dermatol. 2014. (Accepted).

II: Lyth J, Hansson J, Ingvar C, Mansson-Brahme E, Naredi P, Stierner U, Wagenius G, Lindholm C. Prognostic subclassifications of T1 cutaneous melanomas based on ulceration, tumour thickness and Clark's level of invasion: results of a population-based study from the Swedish Melanoma Register. Br J Dermatol. 2013 Apr;168(4):779-86.

III: Eriksson H, Lyth J, Mansson-Brahme E, Frohm-Nilsson M, Ingvar C, Lindholm C, Naredi P, Stierner U, Wagenius G, Carstensen J, Hansson J. Low level of education is associated with later stage at diagnosis and reduced survival in cutaneous malignant melanoma: A nationwide population-based study in Sweden. Eur J Cancer. 2013 Aug;49(12):2705-16.

IV: Lyth J, Carstensen J, Synnerstad I, Lindholm C. Stage-specific direct healthcare costs in patients with cutaneous malignant melanoma. (Submitted). 


\section{ABBREVIATIONS}
AJCC American joint committee on cancer
ALM Acral lentiginous melanoma
CDR Swedish cause of death register
CDWÖ Care data warehouse in Östergötland
CMM Cutaneous malignant melanoma
COX Cox's proportional hazard regression
CPP Cost per patient database
FOB Swedish housing and population censuses
HR Hazard ratio
ICD International classification of disease
KM Method of Kaplan and Meier
LISA Longitudinal integration database for health insurance and labour market studies
LMM Lentigo maligna melanoma
NM Nodular melanoma
OR Odds ratio
PIN Swedish person identity number
PSE Physician skin examination
RCC Regional cancer center
SCR Swedish cancer registry
SEER Surveillance, epidemiology, and end results program
SES Socioeconomic status
SMR Swedish melanoma register
SMSG Swedish melanoma study group
SSE Skin self-examination
SSM Superficial spreading melanoma 


\section{INTRODUCTION}

The Swedish cancer registry (SCR) was started in 1958. The incidence of cutaneous malignant melanoma (CMM) has since then increased, in average about three percent per year. In the last decade, the increase has been even higher and CMM is now the sixth most common cancer type. (1) In Sweden year 2013, there were more than 3000 new cases of CMM and over 500 patients died from the disease (2). Fair skin, the amount of nevi and family history of CMM are the main risk factors and excessive exposure for ultraviolet light increases the development of CMM (3). CMM is a type of skin cancer that arises in the pigment cells of the skin (melanocytes) and about 5$10 \%$ of CMMs are associated with hereditary factors (4).

The prognosis after CMM is good compared to other cancer types with a 5-year survival of about $90 \%$ (5). To diagnose CMM in an early stage is crucial for the prognosis of the patient (6). Until a few years ago there was no effective systematic treatment for patients with metastatic disease. Today new drugs can give a prolonged survival for a minority of patients $(7,8)$.

Despite the prolonged increase of the incidence, no national early detection campaigns have been introduced in Sweden. Some regional activities exist and every year about 3000 persons in Sweden visit dermatology clinics on the Euromelanoma day (9). Skin self-examination (SSE), which is implemented better by women than by men, is important to detect CMM in an early stage (10). People in USA and Australia are more aware of CMM and have a higher frequency of SSE among the population compared to that of northern Europe (11).

Several high-quality registers are available in Sweden, collecting information not only about healthcare data, but also information about socioeconomic status (SES) and other population specific properties on an individual level. The Swedish person identity number (PIN) can then be used to link healthcare data with population-based registers depending on the scientific question (12). This thesis can be partly regarded as an attempt to illustrate the usefulness of these registers by addressing some specific research topics related to CMM. These are introduced at the end of next chapter which 
begins with short explanations of some important terms and continues by providing background descriptions of the registers used. 


\section{BACKGROUND}

\section{Prognostic factors and staging}

Clinical stage at diagnosis: The clinical management of patients with CMM depends primarily on the stage of the disease, which is defined according to the American Joint Committee on Cancer (AJCC) classification. Stages I-II refer to localised disease and in the 2002 version of the AJCC staging system, further sub-classifications are based on tumour thickness, Clark's level of invasion, and tumour ulceration (Table 1). In the most recent version of the AJCC classification, mitotic rate has been added and has replaced Clark's level as the prognostic factor of choice for the thinnest tumours $(\leq 1$ $\mathrm{mm})$. Stage III refers to regional metastatic disease and stage IV refers to distant metastatic disease. Patients in stage III and especially in stage IV have a very poor prognosis compared to patients diagnosed in stage I or II $(6,13,14)$. The term clinical stage is used to denote that metastases are diagnosed using clinical/radiological methods.

Table 1: AJCC 2002 Melanoma Staging.

\begin{tabular}{clc}
\hline Stage & Histologica/TNM Classification & Survival (5-year) $^{\mathrm{a}}$ \\
\hline 0 & Intraepithelia/in situ melanoma (Tis N0 M0) & $100 \%$ \\
IA & $\leq 1 \mathrm{~mm}$ without ulceration and Clark Level II/III (T1a N0 M0) & $95 \%$ \\
IB & $\leq 1 \mathrm{~mm}$ with ulceration or Clark Level IV/V (T1b N0 M0) & $91 \%$ \\
& $1.01-2 \mathrm{~mm}$ without ulceration (T2a N0 M0) & $89 \%$ \\
IIA & $1.01-2 \mathrm{~mm}$ with ulceration (T2b N0 M0) & $77 \%$ \\
& $2.01-4 \mathrm{~mm}$ without ulceration (T3a N0 M0) & $79 \%$ \\
IIB & $2.01-4$ mm with ulceration (T3b N0 M0) & $63 \%$ \\
& $>4$ mm without ulceration (T4a N0 M0) & $67 \%$ \\
IIC & $>4$ mm with ulceration (T4b N0 M0) & $45 \%$ \\
III & Regional metastatis (Any T N1 M0) & $24-69 \%$ \\
IV & Distant metastasis (Any T Any N M1) & $7-19 \%$ \\
\hline
\end{tabular}

${ }^{a}$ Survival data are taken from the AJCC 2002 (14).

Tumour thickness is the most important prognostic factor for CMM patients with localised disease. According to Breslow, tumour thickness is measured from the granular layer of the epidermis to the deepest point of invasion in the dermis (15). 
Tumour thickness is often categorised into T1 $(\leq 1.00 \mathrm{~mm}), \mathrm{T} 2(1.01-2.00 \mathrm{~mm}), \mathrm{T} 3$ (2.01-4.00 mm), and T4 (>4.00 mm). Populations with high distribution of thinner tumours are often referred to as populations with a high grade of awareness of CMM disease, and thus CMMs are diagnosed in an earlier stage. A recent study with Swedish data from the Stockholm/Gotland region has shown a very good agreement among pathologists regarding tumour thickness (16).

Tumour ulceration is defined as tumours with ulceration in the epidermis that is verified by pathologic observation. Tumour ulceration is a strong prognostic factor and is correlated with a worse prognosis for the patient (17). Tumour ulceration is used both in AJCC 2002 and AJCC 2009. A recent study with Swedish data from the Stockholm/Gotland region has shown a good agreement among pathologists regarding tumour ulceration (16).

Clark's level of invasion refers to the anatomical levels of tumour invasion representing epidermis (I), invasion of papillary dermis (II), expansion in papillary dermis (III), invasion of reticular dermis (IV) and invasion of the subcutaneous fat tissue (V) (18). Previously published population-based nationwide Swedish data showed a strong prognostic value of Clark's level of invasion independent of Tcategory (17). A recent study with Swedish data from the Stockholm/Gotland region has shown a fair agreement among pathologists regarding Clark's level of invasion (16).

Histogenetic type has since the seventies consisted of four distinct groups; superficial spreading melanoma (SSM), nodular melanoma (NM), lentigo maligna melanoma (LMM) and acral lentiginous melanoma (ALM). More than half of CMMs are classified as SSM type and NM constitutes about $15-20 \%$. ALM is uncommon in patients with Caucasian origin and LMMs are often associated with very old patients $(2,17)$. SSM and LMM types are often slow growing and take several years to develop into invasive CMMs. NM type is often associated with elderly patients with sun damaged skin. NM often shows a very fast growth (months) and is also sometimes difficult to detect due to vertical growth with a small tumour diameter $(19,20)$. NM 
type is therefore often associated with thick tumours and is sometimes considered as a negative prognostic factor even after adjusting for tumour thickness (17).

Tumour site differs according to gender, as men show a large distribution of CMM located on the trunk and women often have CMMs on the extremities. In multivariable survival analysis, tumour site often has low impact. CMMs located on the trunk and hand/foot/subungual might be associated with a higher risk (17). Gimotty et. al showed that T1 CMMs located to the head/neck were associated with a lower survival compared to other sites (21).

Age and gender are independent prognostic factors. High age is correlated with thicker tumours, but age is also independently associated with lower survival in CMM (17). Younger men have significantly thicker tumours than younger women, but the difference between men and women regarding thickness distribution seems to decrease with increasing age $(2,22)$. Regarding clinical stage at diagnosis, women show a lower frequency with advanced stages III-IV compared to men (17).

\section{Swedish melanoma study group (SMSG) and Swedish melanoma register (SMR)}

Sweden, with about 10 million inhabitants, is divided into six health care regions. In each of these regions, regional CMM groups exist with representatives in plastic and general surgery, dermatology, pathology and oncology. These groups have a close association with the regional cancer centers (RCC) (former oncologic centers), which are responsible for cancer registration and coordination of regional cancer care. The Swedish Melanoma Study Group (SMSG), a multidisciplinary group with members from all health care regions, was established in 1976 with the objective of creating national guidelines for CMM diagnosis, treatment, and follow-up as well as to conduct clinical studies. SMSG made a consensus to collect data on new cases of CMM to support guidelines and since 1990 data has been prospectively gathered concerning clinical characteristics, diagnosis, histopathology and primary treatment on all Swedish cases of CMM (comprehensively since 1996) (17).

Clinical data are now collected by the reporting clinics and monitored/registered at the six RCCs in Sweden within a common database, the SMR. Histopathological data 
for all patients are reported prospectively and electronically from the pathology departments into the population-based nationwide register. SMR includes information of known prognostic factors such as; age, gender, tumour site, clinical stage at diagnosis, tumour thickness, tumour ulceration, Clark's level of invasion, histogenetic type and mitotic rate (for T1 CMM since 2009). The SMR register has a high coverage rate compared to SCR covering over 97\% of CMM cases in Sweden over time with fewer than $3 \%$ of patients lacking information about tumour thickness. SMR thus constitutes a good base for epidemiological studies.

\section{Local databases}

Since 1999, data on all healthcare resources provided by the county of Östergötland have been collected in the Care Data Warehouse in Östergötland (CDWÖ). Data from the healthcare units within the county are transferred each month. All healthcare contacts with a physician (primary care, in and out-patient hospital care) as well as hospitalisation, date, diagnosis (main diagnosis and up to nine secondary diagnoses using ICD-10) are recorded. Since 2005, a Cost per Patient (CPP) database has been available in the county of Östergötland regarding costs for each patient utilising the healthcare system. Standard costs, for instance specific examination and surgical procedures, are calculated separately for each clinic and are based on financial data regarding the healthcare production. Standard costs are then derived for a specific healthcare contact collected from the CDWÖ and summarised to CPP. The CPP database can then be used to calculate the direct costs for different patient groups (23).

CDWÖ could also be used in order to find specific patient groups, but patients with a certain disease often have several preliminary diagnose codes in CDWÖ making it difficult to find certain dates for diagnosis. For cancer patients, the SCR gives a unique possibility to find certain patient groups using international classification of disease (ICD) codes and with a verified date of diagnosis.

\section{Research topics}

Time trends in tumour thickness and patient survival (I):

The annual percentage increase in the age-standardised incidence of CMM was almost $4 \%$ between the year 1999 and 2008, comparable to most western countries except 
Australia (24). Parallel to the increasing incidence of CMM has been a rising proportion of patients diagnosed at an earlier T-category and patient survival has improved considerably during the past decades in Sweden $(25,26)$. This trend has also been observed in several other countries (27-30). In a recent report on patients diagnosed with CMM 1964-2003 in the Nordic countries, Swedish patients had the best survival, but the rate of improvement in survival tended to decline towards the end of that period, especially among women (31). No national Swedish data on trends in the distribution of patients by T-category have been published so far.

\section{Prognostic factors in $T 1$ (thin) CMM (II):}

Few studies are available in population-based settings concerning survival and prognostic factors for T1 CMM. This patient group accounts for the majority of CMMs diagnosed in western countries today and better prognostic information is needed. In AJCC 2009 the mitotic rate has been added as a prognostic factor (6) and research of other new factors is in progress $(32,33)$. However, there are a few studies from Germany, Australia, and USA $(21,33-38)$ that indicate that the previous AJCC 2002 CMM staging (14) could be further refined for T1 CMMs by simply combining the traditional prognostic factors in alternative ways. Due to its size and being population-based, the SMR is ideal when exploring new risk stratifications in T1 CMM.

Level of education in relation to clinical stage and prognosis (III):

A higher SES has been shown to increase the risk of CMM, whereas a worse outcome has been reported for patients with low SES (39-48). Only a few population-based studies have explored CMM prognosis in relation to SES and many of these lack information on SES on the individual level (41, 44-47). To our knowledge, no results have been published from nationwide population-based cohorts with prospectively collected information on multiple prognostic variables. Level of education is an important socioeconomic factor for which high quality data exists in Sweden.

\section{Costs in relation to clinical stage at diagnosis (IV):}

In Sweden, the annual percentage of age-standardised incidence of CMM is increasing and most patients are diagnosed in clinical stage I with relatively good prognosis (24, 
49). This dramatic increase in incidence will have large economic consequences for the healthcare system and, for future planning, the costs per clinical stage need to be calculated. A few studies from USA have analysed direct healthcare costs related to clinical stage, but no such study has been conducted in Europe (50-52). Direct costs are largely related to resources consumed within the health care system, essentially costs for diagnosis, treatment and follow-up. Since 2005, the CPP database in the County of Östergötland, Sweden, includes all costs for each patient utilising the healthcare system and could be used to estimate stage-specific costs in patients diagnosed with CMM. 


\section{AIMS}

The general aim of this thesis was, by using register data, to increase the knowledge of time trends, prognostic factors, socio-economic factors, and healthcare costs in patients diagnosed with CMM.

The specific aims of this thesis were:

- To analyse the recent trends in the distribution of tumour thickness (T-category) as well as trends in CMM-specific survival in Sweden. (I)

- To use established prognostic factors such as tumour ulceration, tumour thickness and Clark's level of invasion for risk stratification of T1 CMM. (II)

- To investigate the association between level of education, clinical stage at diagnosis and CMM-specific survival in Sweden. (III)

- To determine the disease-related direct healthcare costs for patients with CMM in different stages at diagnosis. (IV) 


\section{MATERIALS AND METHODS}

Data from the population-based SMR was used in all papers, but data was also gathered from several other registers. The use of statistical methods depended on the paper-specific aims. Table 2 shows an overview of the papers included in the thesis.

Table 2. Study overview.

\begin{tabular}{|c|c|c|c|c|}
\hline Paper & I & II & III & IV \\
\hline $\begin{array}{l}\text { Study } \\
\text { population }\end{array}$ & 30590 patients with CMM & $\begin{array}{l}13026 \text { patients } \\
\text { with thin }(\mathrm{T} 1) \\
\mathrm{CMM}\end{array}$ & $\begin{array}{l}27235 \\
\text { patients with } \\
\text { CMM }\end{array}$ & $\begin{array}{l}1075 \text { patients with } \\
\text { CMM and } 424982 \\
\text { persons in general } \\
\text { population }\end{array}$ \\
\hline Study area & Sweden & Sweden & Sweden & Östergötland \\
\hline $\begin{array}{l}\text { Inclusion } \\
\text { period }\end{array}$ & $1997-2011$ & $1990-2008$ & $1990-2007$ & $2005-2012$ \\
\hline $\begin{array}{l}\text { Data } \\
\text { sources }\end{array}$ & SMR, CDR & SMR, CDR & $\begin{array}{l}\text { SMR, CDR, } \\
\text { LISA, FOB }\end{array}$ & $\begin{array}{l}\text { SCR, SMR, CDR, } \\
\text { CPP, CDWÖ, local } \\
\text { census register }\end{array}$ \\
\hline $\begin{array}{l}\text { Main } \\
\text { outcome }\end{array}$ & $\begin{array}{l}\text { CMM-specific survival, T- } \\
\text { category }\end{array}$ & $\begin{array}{l}\text { CMM-specific } \\
\text { mortality }\end{array}$ & $\begin{array}{l}\text { CMM- } \\
\text { specific } \\
\text { survival, } \\
\text { clinical stage }\end{array}$ & $\begin{array}{l}\text { Direct healthcare } \\
\text { costs }\end{array}$ \\
\hline $\begin{array}{l}\text { Main } \\
\text { factor(s) }\end{array}$ & Time period of diagnosis & $\begin{array}{l}\text { Tumour thickness, } \\
\text { Clark's level, } \\
\text { tumour ulceration }\end{array}$ & $\begin{array}{l}\text { Level of } \\
\text { education }\end{array}$ & Clinical stage \\
\hline $\begin{array}{l}\text { Statistical } \\
\text { methods }\end{array}$ & $\begin{array}{l}\text { KM, Cox, multinomial } \\
\text { logistic regression, } \\
\text { proportional odds models, } \\
\text { direct standardisation }\end{array}$ & KM, Cox & $\begin{array}{l}\text { KM, Cox, } \\
\text { logistic } \\
\text { regression }\end{array}$ & $\begin{array}{l}\text { Direct } \\
\text { standardisation, } \\
\text { KM }\end{array}$ \\
\hline
\end{tabular}

Abbreviations: KM: Method of Kaplan and Meier; Cox: Cox's Proportional Hazard Regression; SMR:

Swedish Melanoma Register; CDR: Cause of Death Register; SCR: Swedish Cancer Registry; LISA:

Longitudinal Integration Database for Health Insurance and Labour Market Studies; FOB: Swedish

Housing and Population Censuses; CPP: The Cost per Patient database; CDWÖ: The Care Data

Warehouse in Östergötland. 


\section{Paper I}

During the time period 1997-2011, 31098 primary invasive CMMs were collected from SMR. The SCR and SMR were then used to exclude from analysis patients with invasive CMM diagnosed before 1997 ( $\mathrm{n}=508)$. Among the remaining 30590 patients with a first primary invasive CMM, only 828 patients lacked information on T-category. The following variables from SMR were used in the present study: gender, age at diagnosis, date of diagnosis, tumour site, health care region, and T-category. Date and cause of death until December 31, 2012 were obtained from the Swedish cause of death register (CDR).

All statistical analyses were performed for men and women separately. Two groups were defined in the age-specific analyses; $<65$ and $\geq 65$ years. In multivariable analyses, age was further categorised into five groups $(\leq 39,40-54,55-64,65-79$ and $\geq 80$ years). Tumour thickness was analysed as a categorical variable grouped according to the AJCC 2002 classification as T1 $(\leq 1.0 \mathrm{~mm}), \mathrm{T} 2(1.01-2.0 \mathrm{~mm}), \mathrm{T} 3$ (2.01-4.0 $\mathrm{mm})$ and T4 (>4.0 $\mathrm{mm})(14)$.

To evaluate the association between time period and T-category at diagnosis, a multinomial logistic regression was used with T1 CMMs as reference (53). The results were expressed as odds ratios (OR) with 95\% confidence intervals (CI). Proportional odds models were used to obtain $p$-values for OR trends over T-category (53). All logistic models also included age, tumour site, and health care region to adjust for any potential confounding effects of these variables.

Survival time was calculated from the date of diagnosis until death from CMM or to the date of censoring (emigration, diagnosis of a second CMM, death from causes other than CMM, or the cut-off date, December 31, 2012). CMM-specific survival and CI were estimated using the method of Kaplan and Meier (54). Cox regression was used to assess the independent prognostic contribution of time period of diagnosis after adjustment for the confounders' age and tumour site (53). The prognostic impacts were expressed as hazard ratios (HRs) with 95\% CIs. Using stratified Cox regression models, the analyses were adjusted for health care region. Patients with missing data regarding tumour site or T-category were excluded from the analyses. 


\section{Paper II}

During the time period 1997-2011, 13026 first primary invasive thin (T1) CMMs in clinical stage I were collected from SMR and were used in a univariable Kaplan-Meier analysis of CMM-specific 5-, 10 and 15-year mortality rates.

A Cox analysis for prognostic factors was undertaken on 11165 patients aged 1589 years including all types of CMM except ALM and except CMM tumours localised to the palm/subungual areas (53).

The following variables from SMR were used in the present study: age at diagnosis, gender, tumour site, tumour thickness, Clark's level of invasion, tumour ulceration and histogenetic type. Date and cause of death until December 31, 2009 were obtained from CDR. Survival time was calculated from the date of diagnosis until death from CMM or to the date of censoring (emigration, diagnosis of a second CMM, death from causes other than CMM, or the cut-off date, December 31, 2009).

Results from the Cox analysis and mortality rates were used in order to create three different risk groups for T1 CMMs.

\section{Paper III}

During the time period 1990-2007, 27235 first primary invasive CMMs were collected from SMR. In order to collect information on level of education, patients were individually linked to the longitudinal integration database for health insurance and labour market studies (LISA) as well as to the Swedish housing and population censuses (FOB) 1960-1990.

Education was classified according to the highest educational level completed at the time of diagnosis: low $\leq 9$ years, intermediate $10-12$ years and high $\geq 13$ years, which in Sweden corresponds to mandatory school, high school and college/university. If information was missing in the LISA database, information was gathered from the most recent information in FOB 1960-1990.

The following variables from SMR were used in the present study: age at diagnosis, gender, time period of diagnosis, tumour site, tumour thickness, clinical 
stage at diagnosis, histogenetic type, tumour ulceration, tumour thickness, Clark's level of invasion and living area. Living area was categorised as metropolitan: $>200$ 000 inhabitants (the cities of Stockholm, Göteborg and Malmö with suburban municipalities); urban: 50 000-200 000 inhabitants; rural: $<50000$ inhabitants. Except for tumour thickness all prognostic factors were treated as categorical variables.

Survival time was calculated from the date of diagnosis until death from CMM or to the date of censoring (emigration, diagnosis of a second CMM, death from causes other than CMM, or the cut-off date, December 31, 2010). Date and cause of death were obtained from CDR.

Cumulative CMM-specific survival probabilities and CIs were estimated using the method of Kaplan and Meier (54). The log rank test was performed to compare survival curves. Cox's proportional hazard regressions with different types of adjustments were used to assess the independent prognostic contribution of level of education. The prognostic impact was expressed as HRs with 95\% CIs (53). Using stratified Cox regression models the analyses were adjusted for health care region. In the multivariable Cox-analysis, the non-proportional assumption (time-dependence) was tested for each prognostic variable comparing $\leq 5$ years after diagnosis and $>5$ years after diagnosis.

In order to evaluate the association between education and clinical stage at diagnosis (three levels), a multinomial logistic regression was used (53). In the analysis, stage III and IV at diagnosis were grouped together because of the small numbers in stage IV. The results from the logistic regressions were expressed as ORs with $95 \%$ CIs.

\section{Paper IV}

In this study, several population-based registers were linked via PIN; SMR, SCR, CDR, CDWÖ, CPP and a local census register. CPP contains costs associated with all healthcare contacts per patient including inpatient, outpatient, and primary care.

From the SCR, 1090 CMM patients diagnosed with a first invasive CMM during 2005-2012 in the County of Östergötland were identified. Clinical stage at diagnosis 
was obtained from SMR in 1075 patients (98.6\%) who were used in further analyses with follow up until December 31, 2012. The follow-up was ended early if the patient moved outside the County of Östergötland or died before December 31, 2012.

The CMM-related (additional) costs were defined as the difference in mean healthcare costs between CMM patients and the general population. To adjust for differences in age and gender between CMM patients and the general population, cost estimates for the general population were standardised according to the age (five year intervals) and gender distribution of the CMM patients. A healthcare cost ratio was defined as the ratio of mean costs for CMM patients to the mean costs in the general population. CIs (95\%) were given for the healthcare cost ratios and the delta method was used to derive standard errors (53). During the first year after diagnosis, unadjusted and stage-adjusted CMM-related costs were calculated for five age groups and by gender. The adjustment for clinical stage was done by weighting the stagespecific costs in each age and gender group and according to the distribution in stage in the entire group of CMM patients. CMM-specific survival per clinical stage with 95\% CIs was estimated using the method of Kaplan and Meier.

\section{Ethical considerations}

In all papers in this thesis several linked data sources were used and consent by ethics committees was thus required. Papers I and II (multicenter study) was approved by the Regional Ethics Committees at Linköping, Göteborg, Lund, Stockholm, Umeå and Uppsala (dnr 99160). Paper III was approved by the Regional Ethics Committee at Karolinska Institutet (Stockholm, Sweden) (dnr, 2009/1041-31). Paper IV was approved by The Regional Ethics Committee at Linköping (dnr 2012/303-31). 


\section{RESULTS}

This section presents the study-specific results from the papers.

\section{Paper I}

A total of 30590 patients diagnosed 1997-2011 with a first primary invasive CMM were included in the study with a median follow-up time of 4.8 years (range 0-16 years). During 2007-2011 50.7\% of men and 57.4\% of women diagnosed with CMM had T1 CMM compared with $48.4 \%$ and $57.1 \%$ in 1997-2001. During this time period men had a higher median age compared to women with 65 and 61 years, respectively. Both age and gender differences were found in the distribution of Tcategory (Figure 1).

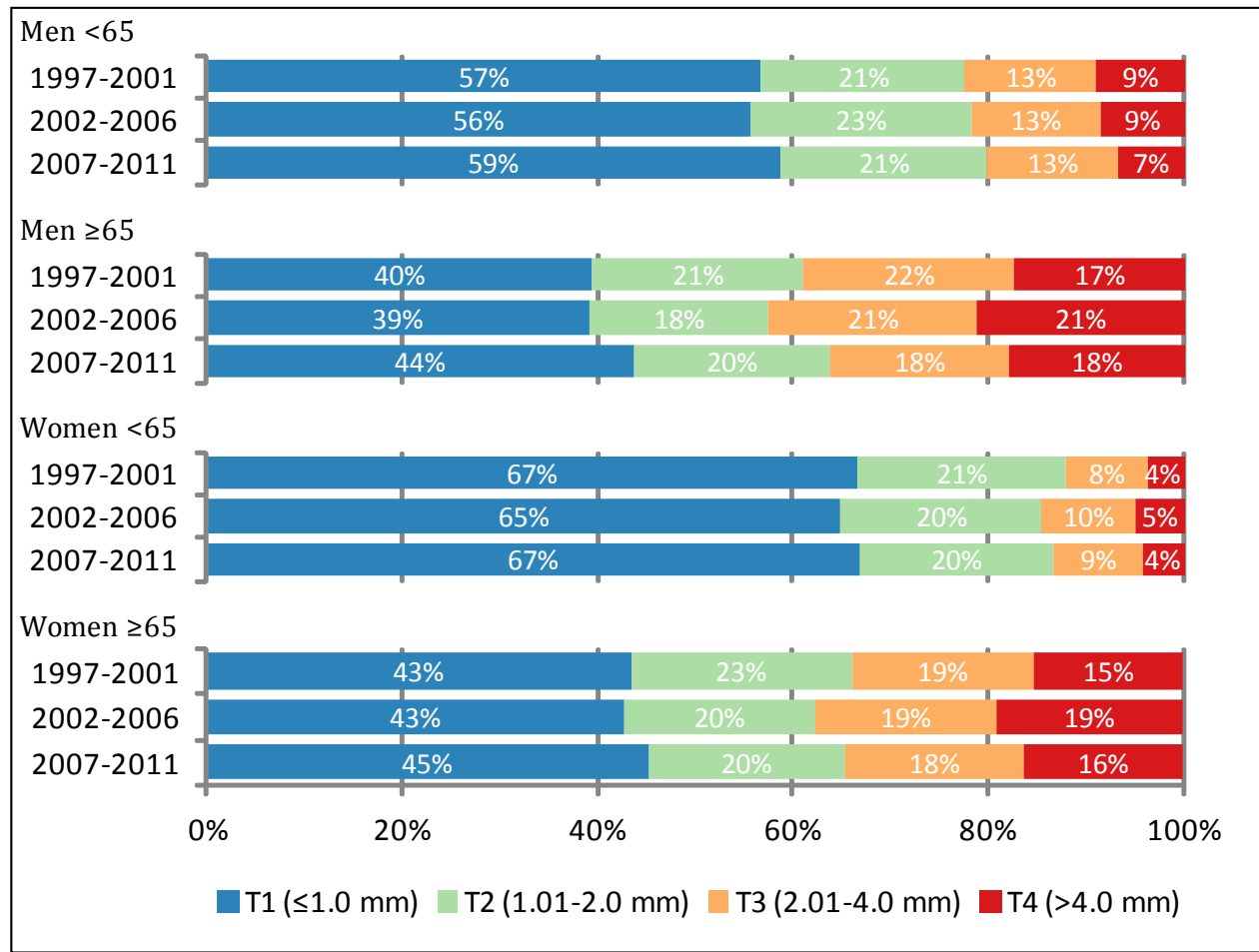

Figure 1. Distribution of T-category by gender and age for three time periods in 29762 patients diagnosed with primary invasive cutaneous malignant melanoma in Sweden, 19972011. 
In the logistic regression analysis after adjustments for age, tumour site and health care region, there was a statistically significant shift towards thinner tumours during 2007-2011 compared to 1997-2001 for men $(p=0.0008)$ but not for women $(p=$ $0.60)$. This trend towards thinner tumours was seen in both the younger $(p=0.02)$ and older $(p=0.01)$ age groups for men. Compared with 1997-2001, the proportion of T4 CMMs decreased significantly during 2007-2011 for younger men and the proportions of T2 and T3 CMM decreased significantly in older men. In men there was a tendency towards a higher proportion of T4 tumours in 2002-2006 which was significant in older men. For women diagnosed between 2002 and 2006, there was a significant change towards thicker tumours compared to those diagnosed between 1997 and 2001 $(p=0.02)$. (Table 3) However, women diagnosed 2007-2011 shifted back towards thinner tumours compared to 2002-2006 $(p=0.002)$.

Table 3. Association between time period of diagnosis and T-category by age and gender in $29624^{\mathrm{a}}$ patients diagnosed with primary invasive cutaneous malignant melanoma in Sweden, 1997-2011.

\begin{tabular}{|c|c|c|c|c|c|}
\hline & $\begin{array}{c}\mathrm{T} 1(\leq 1.0 \mathrm{~mm})(\mathrm{ref}) \\
\text { OR }(95 \% \mathrm{CI})^{\mathrm{b}}\end{array}$ & $\begin{array}{c}\mathrm{T} 2(1.01-2.0 \mathrm{~mm}) \\
\text { OR }(95 \% \mathrm{CI})^{\mathrm{b}}\end{array}$ & $\begin{array}{c}\text { T3 }(2.01-4.0 \mathrm{~mm}) \\
\text { OR }(95 \% \mathrm{CI})^{\mathrm{b}}\end{array}$ & $\begin{array}{l}\text { T4 }(>4.0 \mathrm{~mm}) \\
\text { OR }(95 \% \mathrm{CI})^{\mathrm{b}}\end{array}$ & $P$ trend $^{\mathrm{c}}$ \\
\hline \multicolumn{6}{|c|}{$2007-2011$ vs $1997-2001$} \\
\hline Men & 1 & $0.90(0.81-1.01)$ & $0.83(0.74-0.93)$ & $0.85(0.75-0.97)$ & 0.0008 \\
\hline$<65$ & 1 & $0.97(0.84-1.12)$ & $0.94(0.79-1.12)$ & $0.70(0.56-0.88)$ & 0.02 \\
\hline$\geq 65$ & 1 & $0.83(0.71-0.97)$ & $0.75(0.64-0.88)$ & $0.91(0.77-1.07)$ & 0.01 \\
\hline Women & 1 & $0.89(0.80-0.99)$ & $0.99(0.87-1.13)$ & $1.04(0.89-1.21)$ & 0.60 \\
\hline$<65$ & 1 & $0.92(0.81-1.05)$ & $1.07(0.89-1.30)$ & $1.07(0.82-1.41)$ & 0.89 \\
\hline$\geq 65$ & 1 & $0.84(0.72-0.99)$ & $0.92(0.77-1.09)$ & $0.99(0.82-1.20)$ & 0.50 \\
\hline \multicolumn{6}{|c|}{$2002-2006$ vs $1997-2001$} \\
\hline Men & 1 & $0.97(0.87-1.09)$ & $0.99(0.87-1.11)$ & $1.13(0.99-1.29)$ & 0.28 \\
\hline$<65$ & 1 & $1.08(0.93-1.26)$ & $0.99(0.82-1.19)$ & $0.96(0.77-1.20)$ & 1.00 \\
\hline$\geq 65$ & 1 & $0.85(0.72-1.01)$ & $0.98(0.83-1.15)$ & $1.21(1.01-1.44)$ & 0.16 \\
\hline Women & 1 & $0.94(0.84-1.05)$ & $1.08(0.94-1.23)$ & $1.31(1.12-1.54)$ & 0.02 \\
\hline$<65$ & 1 & $0.99(0.86-1.13)$ & $1.15(0.94-1.41)$ & $1.33(1.01-1.76)$ & 0.12 \\
\hline$\geq 65$ & 1 & $0.87(0.73-1.04)$ & $0.99(0.82-1.20)$ & $1.26(1.03-1.53)$ & 0.10 \\
\hline
\end{tabular}

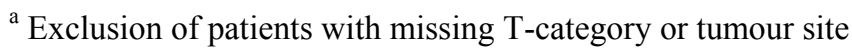

${ }^{\mathrm{b}}$ Model adjusted for age, tumour site and health care region

${ }^{c}$ Proportional odds model was used to get $\mathrm{p}$ values for trend over T-category 
The 5-year CMM-specific survival among men increased from 84.7\% in 19972001 to $86.8 \%$ in $2007-2011$. Among women, the survival increased only marginally from $91.8 \%$ in $1997-2001$ to $92.5 \%$ in $2007-2011$ (Figure 2).

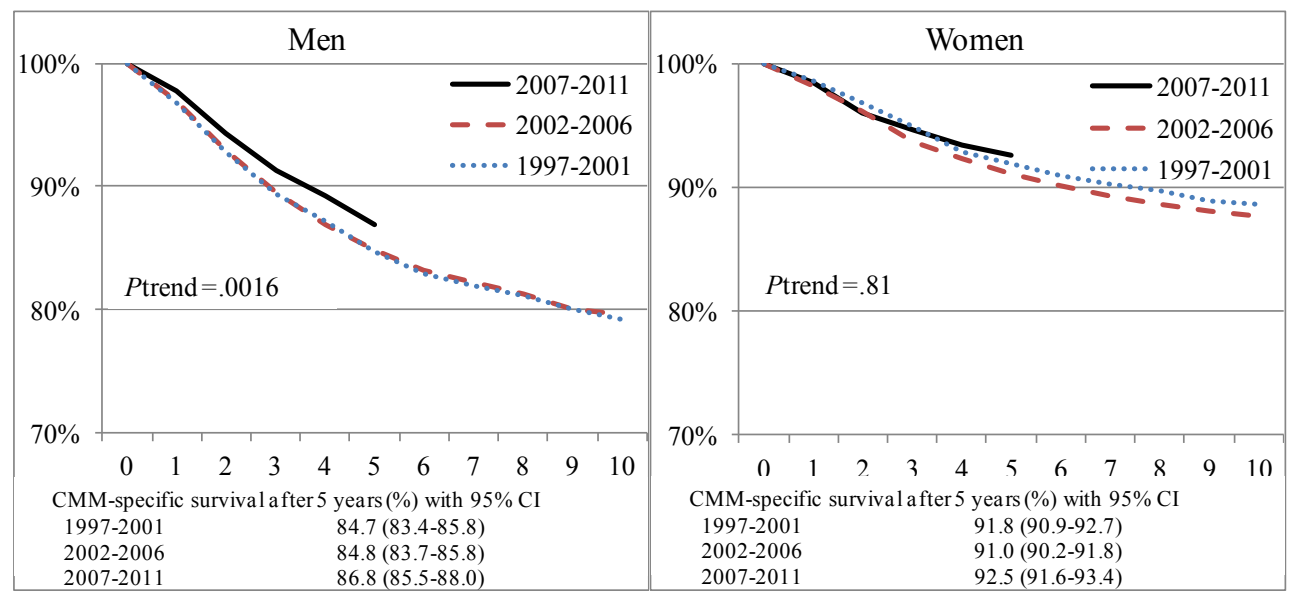

Figure 2. Kaplan-Meier estimates showing the proportion of patients in Sweden surviving from cutaneous malignant melanoma $(\mathrm{CMM})$ by gender and time period of diagnosis $(n=30590)$.

In Cox regression analyses adjusted for age, tumour site and health care region, there were significant improvements in CMM-specific survival over time periods for men $(p$ trend $=0.0009)$. A 19\% lower CMM death rate was found in men diagnosed 2007-2011 compared to men diagnosed 1997-2001, $(\mathrm{HR}=0.81 ; 95 \% \mathrm{CI}=0.72-0.91)$. The improved survival was seen in both the younger $(p=0.01)$ and older $(p=0.02)$ age groups for men. No significant differences were observed in women, but a tendency towards worse survival was seen in women diagnosed during 2002-2006, $(\mathrm{HR}=1.10 ; 95 \% \mathrm{CI}=0.96-1.25)$.

\section{Paper II}

A total of 13026 patients diagnosed 1990-2008 with primary invasive $\mathrm{T} 1(\leq 1.0 \mathrm{~mm})$ CMM were included in the study with a median follow-up time of 6.6 years (range 0 to 20 years). During follow-up 311 (2.4\%) patients died from CMM and 1731 (13.3\%) patients died of other causes. The overall 10- and 15-year CMM-specific mortality rates were $3.4 \%(3.0-3.8 \%)$ and $4.4 \%(3.9-5.0 \%)$, respectively. 
In a multivariable Cox analysis tumour ulceration, tumour thickness and Clark's level of invasion were the most important prognostic factors. The highest hazard ratios were observed for ulceration versus non-ulceration $(\mathrm{HR}=3.2 ; 95 \% \mathrm{CI}=2.3-4.4)$, tumour thickness $>0.75 \mathrm{~mm}$ versus $\leq 0.5 \mathrm{~mm}(\mathrm{HR}=2.8 ; 95 \% \mathrm{CI}=1.9-4.1)$ and Clark IV-V versus Clark II $(\mathrm{HR}=2.1 ; 95 \% \mathrm{CI}=1.4-3.3)$. In a further multivariable Cox analysis of all potential interaction effects, there was a significant interaction between tumour thickness and tumour ulceration $(p=0.03)$. This interaction indicates that tumour thickness was a less important prognostic factor when the CMM was ulcerated (HR: 0.8 for $>0.75 \mathrm{~mm}$ versus $\leq 0.5 \mathrm{~mm} ; 95 \% \mathrm{CI}=0.3-1.9)$ compared with non-ulcerated CMMs (HR: 3.5 for $>0.75 \mathrm{~mm}$ versus $\leq 0.5 \mathrm{~mm}$; $95 \% \mathrm{CI}=2.3-5.4$ ). This is further illustrated by the 10-year CMM-specific mortality rates by tumour ulceration, tumour thickness and Clark's level of invasion (Table 4).

Table4. 10-year CMM-specific mortality rates by tumour ulceration, Clark's level of invasion and tumour thickness, 1990-2008 (N=11 165).

\begin{tabular}{|c|c|c|c|c|}
\hline \multirow[b]{3}{*}{ Clark level/Tumour thickness } & \multicolumn{4}{|c|}{ Tumour ulceration } \\
\hline & \multicolumn{2}{|r|}{ No } & \multicolumn{2}{|r|}{ Yes } \\
\hline & $\mathrm{n}(\%)$ & Mortality $(95 \% \mathrm{CI})$ & $\mathrm{n}(\%)$ & Mortality $(95 \% \mathrm{CI})$ \\
\hline \multicolumn{5}{|l|}{ Clark level II } \\
\hline$\leq 0.5 \mathrm{~mm}$ & $4072(36.5)$ & $0.9(0.6-1.4)$ & $93(0.8)$ & $7.0(2.9-16.6)$ \\
\hline $0.51-0.75 \mathrm{~mm}$ & $1302(11.7)$ & $1.6(0.9-2.9)$ & $46(0.4)$ & $5.8(1.5-21.7)$ \\
\hline$>0.75 \mathrm{~mm}$ & $452(4.1)$ & $5.0(2.8-9.0)$ & $48(0.4)$ & $13.3(3.5-43.6)$ \\
\hline \multicolumn{5}{|l|}{ Clark level III } \\
\hline$\leq 0.5 \mathrm{~mm}$ & $744(6.6)$ & $2.0(1.0-4.1)$ & $26(0.2)$ & $17.4(4.2-57.2)$ \\
\hline $0.51-0.75 \mathrm{~mm}$ & $1463(13.1)$ & $3.0(2.0-4.4)$ & $73(0.7)$ & $12.5(5.7-26.2)$ \\
\hline$>0.75 \mathrm{~mm}$ & $1798(16.1)$ & $6.2(4.8-7.9)$ & $168(1.5)$ & $14.7(8.8-23.9)$ \\
\hline \multicolumn{5}{|l|}{ Clark level IV-V } \\
\hline$\leq 0.5 \mathrm{~mm}$ & $78(0.7)$ & $4.0(1.0-16.0)$ & $10(0.1)$ & $11.1(1.6-56.7)$ \\
\hline $0.51-0.75 \mathrm{~mm}$ & $180(1.6)$ & $6.5(2.9-14.1)$ & $8(0.1)$ & $25.0(6.9-68.5)$ \\
\hline$>0.75 \mathrm{~mm}$ & $548(4.9)$ & $6.6(4.4-10.0)$ & $56(0.5)$ & $24.0(11.6-45.6)$ \\
\hline
\end{tabular}

Using the results in Table 4, the T1 CMMs were divided into three risk groups: a low risk group of non-ulcerated Clark II-III $\leq 0.75 \mathrm{~mm}$ CMMs (67.9\% of T1 cases) with a 10 -year CMM-specific mortality rate of 1.5\% (1.2-1.9\%); an intermediate risk group of CMMs that were non-ulcerated $>0.75 \mathrm{~mm}$; or non-ulcerated Clark IV-V; or ulcerated Clark II $\leq 0.75 \mathrm{~mm}$ (28.6\% of T1 cases) with a 10-year CMM-specific 
mortality rate of $6.1 \%(5.0-7.3 \%)$; and a high risk group consisting of all ulcerated T1 CMMs except Clark II $\leq 0.75 \mathrm{~mm}$ (3.5\% of T1 cases) with a 10-year CMM-specific mortality rate of $15.6 \%(11.2-21.4 \%)$. Figure 3 shows the cumulative CMM-specific mortality for the three risk groups.

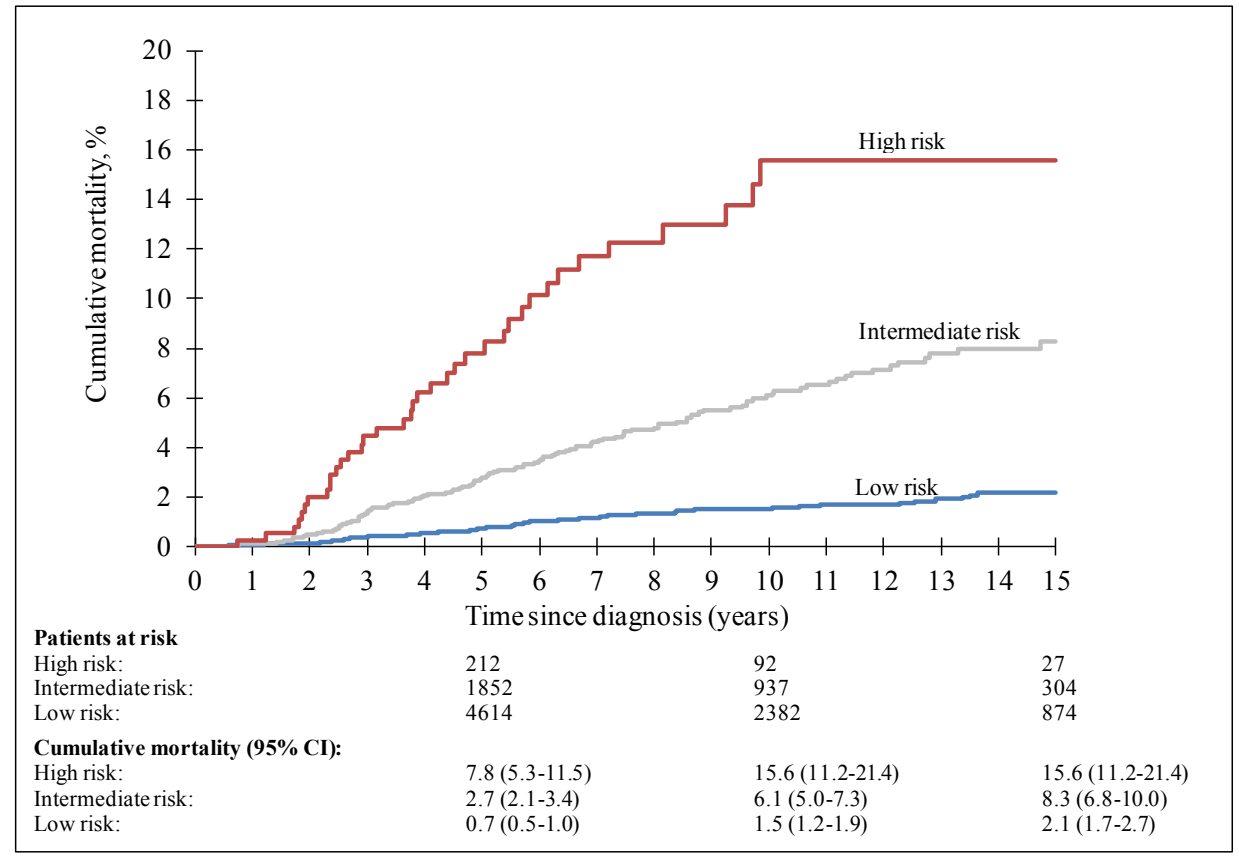

Figure 3. Cumulative CMM-specific mortality by group

Low risk group: Non-ulcerated $\leq 0.75 \mathrm{~mm} \&$ Clark II-III; Intermediate risk group: Nonulcerated $>0.75 \mathrm{~mm}$; or non-ulcerated \& Clark IV-V; or ulcerated $\leq 0.75 \mathrm{~mm} \&$ Clark II; High risk group: Ulcerated \& Clark III-V; or ulcerated $>0.75 \mathrm{~mm} \&$ Clark II.

\section{Paper III}

A total of 27235 patients diagnosed 1990-2007 with primary invasive CMM were included in the study with a median follow-up time of 6.9 years (range 0 to 21 years). During the observation period almost $14 \%$ of the patients died due to CMM and more than $20 \%$ died of other causes.

Overall, $34 \%$ of the patients were categorised as having low education, $37 \%$ intermediate and $24 \%$ high education, (information missing in $4.0 \%$ ). The median age 
was much higher in the low education group compared to the high education group with 70 and 54 years, respectively.

Table 5. Hazard ratios (HRs) with corresponding $95 \%$ confidence intervals (CIs) for CMMspecific death by level of education in 18531 patients diagnosed with primary invasive cutaneous malignant melanoma in Sweden, 1990-2007 ${ }^{\mathrm{a}}$.

\begin{tabular}{|c|c|c|c|c|}
\hline \multirow[b]{2}{*}{ Stratification group } & \multicolumn{2}{|c|}{ Adjusted for age and gender } & \multicolumn{2}{|c|}{ Adjusted for age, gender and clinical stage } \\
\hline & $\begin{array}{l}\text { Low vs High } \\
\text { HR }(95 \% \mathrm{CI}) \\
\end{array}$ & $\begin{array}{c}\text { Intermediate vs High } \\
\text { HR }(95 \% \mathrm{CI}) \\
\end{array}$ & $\begin{array}{l}\text { Low vs High } \\
\text { HR }(95 \% \mathrm{CI}) \\
\end{array}$ & $\begin{array}{c}\text { Intermediate vs High } \\
\mathrm{HR}(95 \% \mathrm{CI})\end{array}$ \\
\hline All patients & $1.58(1.40-1.77)$ & $1.30(1.16-1.46)$ & $1.19(1.06-1.34)$ & $1.13(1.01-1.27)$ \\
\hline \multicolumn{5}{|l|}{ Gender } \\
\hline Men & $1.37(1.19-1.58)$ & $1.26(1.10-1.44)$ & $1.08(0.94-1.24)$ & $1.14(0.99-1.31)$ \\
\hline Women & $2.01(1.63-2.48)$ & $1.41(1.14-1.73)$ & $1.42(1.15-1.76)$ & $1.14(0.93-1.41)$ \\
\hline \multicolumn{5}{|l|}{ Age } \\
\hline$<55$ & $1.95(1.56-2.44)$ & $1.31(1.08-1.59)$ & $1.48(1.18-1.85)$ & $1.11(0.92-1.35)$ \\
\hline $55-69$ & $1.58(1.30-1.93)$ & $1.38(1.13-1.68)$ & $1.24(1.01-1.50)$ & $1.25(1.03-1.53)$ \\
\hline$\geq 70$ & $1.36(1.12-1.65)$ & $1.18(0.96-1.46)$ & $1.02(0.84-1.24)$ & $1.03(0.84-1.28)$ \\
\hline \multicolumn{5}{|l|}{ Living area } \\
\hline Metropolitan & $1.62(1.35-1.95)$ & $1.26(1.06-1.50)$ & $1.20(1.00-1.44)$ & $1.07(0.90-1.28)$ \\
\hline Urban other/Rural & $1.53(1.31-1.78)$ & $1.32(1.13-1.54)$ & $1.18(1.01-1.38)$ & $1.17(1.00-1.37)$ \\
\hline \multicolumn{5}{|l|}{ Period of diagnosis } \\
\hline $1990-1995$ & $1.46(1.14-1.88)$ & $1.20(0.93-1.53)$ & $1.15(0.89-1.48)$ & $1.05(0.82-1.34)$ \\
\hline $1996-2001$ & $1.48(1.21-1.79)$ & $1.29(1.06-1.56)$ & $1.08(0.89-1.32)$ & $1.11(0.91-1.34)$ \\
\hline $2002-2007$ & $1.69(1.41-2.02)$ & $1.36(1.14-1.62)$ & $1.23(1.03-1.48)$ & $1.16(0.97-1.38)$ \\
\hline \multicolumn{5}{|l|}{ Tumor site } \\
\hline Head/Neck & $1.16(0.84-1.59)$ & $1.05(0.76-1.44)$ & $0.82(0.59-1.13)$ & $0.81(0.58-1.11)$ \\
\hline Extremities & $1.44(1.18-1.76)$ & $1.25(1.03-1.52)$ & $1.07(0.88-1.31)$ & $1.05(0.87-1.28)$ \\
\hline Trunk & $1.92(1.62-2.27)$ & $1.46(1.24-1.73)$ & $1.49(1.25-1.76)$ & $1.33(1.13-1.58)$ \\
\hline
\end{tabular}

${ }^{a}$ Exclusion of patients from the multivariable analyses with missing data on level of education, clinical stage at diagnosis, tumour site, histogenetic type, tumour ulceration, tumour thickness and Clark's level of invasion. All proportional hazard models are stratified by health care region.

The result showed that the unadjusted risk of dying of CMM was twice as high $(\mathrm{HR}=2.02 ; 95 \% \mathrm{CI}=1.80-2.26 ; p<0.001)$ in patients with low education compared to high education. When adjusting for age and gender the hazard ratio was still increased in both patients with low $(\mathrm{HR}=1.58 ; 95 \% \mathrm{CI}=1.40-1-77 ; p<0.001)$ and intermediate education $(\mathrm{HR}=1.30 ; 95 \% \mathrm{CI}=1.16-1.46 ; p<0.001)$. After adjusting for age, gender, and clinical stage at diagnosis the effect remained 19\% higher $(\mathrm{HR}=1.19 ; 95 \%$ $\mathrm{CI}=1.06-1.34 ; p<0.001$ ) in patients with low education (Table 5). Further adjustments 
with additional prognostic factors as tumour site, histogenetic type, tumour ulceration, tumour thickness, Clark's level of invasion, living area and time period of diagnosis, only decreased the effect slightly to $13 \%$ higher $(\mathrm{HR}=1.13 ; 95 \% \mathrm{CI}=1.01-1.27$; $p=0.04)$ in patients with low education.

The difference in stage distribution by level of education was significant in all gender and age groups. Among patients 69 years or younger, women with low education had equal stage distribution as men with high education (Figure 4).

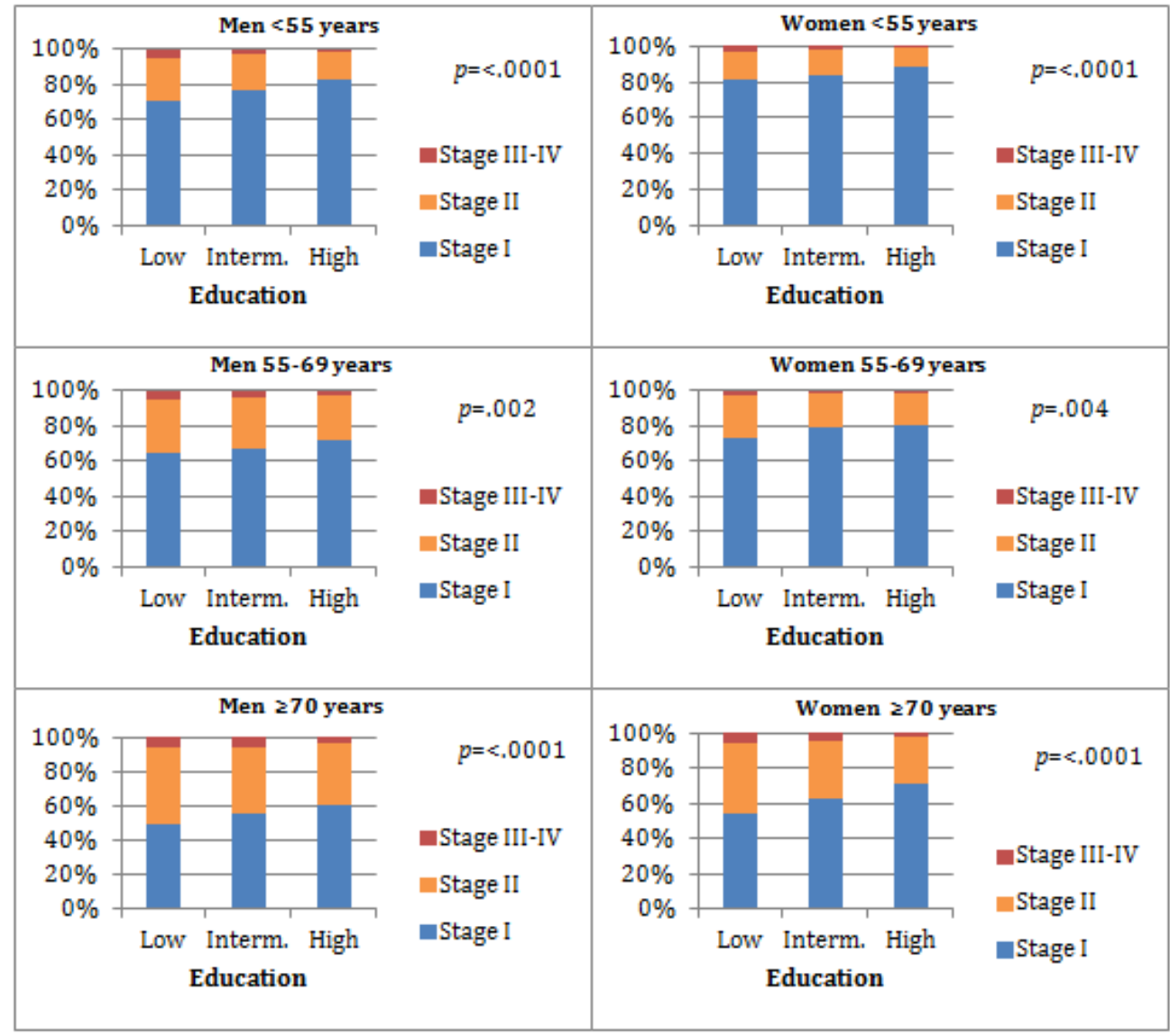

Figure 4. The distribution of patients diagnosed with a primary cutaneous malignant melanoma by clinical stage at diagnosis and level of education at diagnosis for men and women according to age-group $(\mathrm{N}=20,518 *)$. Exclusion of patients from the analyses with missing data on education, clinical stage at diagnosis and tumour site. 
The unadjusted odds of being diagnosed in clinical stage III-IV versus stage I was three times as high $(\mathrm{OR}=3.0 ; 95 \% \mathrm{CI}=2.4-3.7 ; p<0.001)$ for low education compared to high education. The adjusted OR was $2.3(95 \% \mathrm{CI}=1.8-2.9 ; p<0.001)$ (Table 6).

Table 6. Association between level of education and clinical stage at diagnosis in $20518^{\mathrm{a}}$ patients diagnosed with primary invasive cutaneous malignant melanoma in Sweden, 19902007.

\begin{tabular}{|c|c|c|}
\hline & \multicolumn{2}{|c|}{ Adjusted model ${ }^{\mathrm{b}}$} \\
\hline & $\begin{array}{c}\text { Stage II versus I } \\
\text { OR }(95 \% \mathrm{CI})\end{array}$ & $\begin{array}{c}\text { Stage III-IV versus I } \\
\text { OR }(95 \% \mathrm{CI}) \\
\end{array}$ \\
\hline \multicolumn{3}{|c|}{ Level of education } \\
\hline High & 1.0 (ref) & 1.0 (ref) \\
\hline Intermediate & $1.3(1.2-1.4)$ & $1.6(1.2-1.9)$ \\
\hline Low & $1.6(1.5-1.7)$ & $2.3(1.8-2.9)$ \\
\hline
\end{tabular}

${ }^{a}$ Exclusion of patients from the analyses with missing data on education, clinical stage at diagnosis and tumour site

${ }^{\mathrm{b}}$ Model adjusted for age, gender, tumour site, living area, time period of diagnosis and health care region

\section{Paper IV}

A total of 1075 patients diagnosed 2005-2012 with primary invasive CMM were included in the study with a median follow-up time of 2.6 years (range 0 to 8 years). The majority of patients (68.5\%) were diagnosed in clinical stage I.

The first year after diagnosis, CMM-related costs per patient-year varied from $€ 2$ 670 (stage I) to $€ 29291$ (stage IV). Patients in clinical stage III-IV (7\% of CMM patients) accounted for $27 \%$ of the total healthcare costs during the first year (Table 7 ). 
Table 7. Direct healthcare costs in 1075 patients with cutaneous malignant melanoma (CMM) by time periods after diagnoses and clinical stage in the County of Östergötland, Sweden 2005-2012.

\begin{tabular}{|c|c|c|c|c|c|c|c|c|}
\hline Category & $\begin{array}{l}\text { Number } \\
\text { of } \\
\text { CMM } \\
\text { patients }\end{array}$ & $\begin{array}{l}\text { Number } \\
\text { of } \\
\text { patient- } \\
\text { years }\end{array}$ & $\begin{array}{l}\text { Costs } \\
\text { per } \\
\text { patient- } \\
\text { year }(€)\end{array}$ & $\begin{array}{l}\text { Costs per } \\
\text { person- } \\
\text { year in } \\
\text { general } \\
\text { population } \\
(€)\end{array}$ & $\begin{array}{l}\text { Healthcare cost } \\
\text { ratio }(95 \% \mathrm{CI})^{\mathrm{a}}\end{array}$ & $\begin{array}{l}\text { CMM- } \\
\text { related } \\
\text { costs }(€) \\
\text { per } \\
\text { patient- }^{\text {bear }} \\
\text { year }\end{array}$ & $\begin{array}{l}\text { Total } \\
\text { CMM- } \\
\text { related } \\
\text { costs } \\
(€ 1000)\end{array}$ & $\begin{array}{l}\text { Share of } \\
\text { total } \\
\text { CMM- } \\
\text { related } \\
\text { costs }\end{array}$ \\
\hline \multirow{2}{*}{\multicolumn{9}{|c|}{$\begin{array}{l}\text { Clinical stage } \\
\text { at diagnosis } \\
\text { Year }<1\end{array}$}} \\
\hline & & & & & & & & \\
\hline I & 736 & 669.0 & 5448 & 2778 & $2.0(1.8-2.2)$ & 2670 & 1786 & $34.4 \%$ \\
\hline II & 265 & 239.9 & 12187 & 3793 & $3.2(2.9-3.6)$ & 8394 & 2014 & $38.8 \%$ \\
\hline III & 56 & 47.4 & 23637 & 2907 & $8.1(6.7-9.9)$ & 20730 & 983 & $18.9 \%$ \\
\hline IV & 18 & 13.9 & 32505 & 3214 & $10.1(7.2-14.2)$ & 29291 & 407 & $7.8 \%$ \\
\hline \multicolumn{9}{|l|}{ Year 1-3 } \\
\hline I & 599 & 946.9 & 3654 & 2772 & $1.3(1.2-1.5)$ & 882 & 835 & $26.7 \%$ \\
\hline II & 215 & 322.3 & 8874 & 3814 & $2.3(2.0-2.7)$ & 5060 & 1631 & $52.1 \%$ \\
\hline III & 38 & 54.1 & 10863 & 2656 & $4.1(2.9-5.7)$ & 8207 & 444 & $14.2 \%$ \\
\hline IV & 11 & 15.7 & 16623 & 2645 & $6.3(3.7-10.6)$ & 13978 & 219 & $7.0 \%$ \\
\hline \multicolumn{9}{|l|}{ Year $\geq 3$} \\
\hline I & 324 & 676.1 & 3396 & 2765 & $1.2(1.1-1.4)$ & 631 & 426 & $39.2 \%$ \\
\hline II & 114 & 247.6 & 5588 & 3954 & $1.4(1.1-1.7)$ & 1634 & 405 & $37.2 \%$ \\
\hline III & 21 & 41.2 & 6803 & 2511 & $2.7(1.7-4.4)$ & 4292 & 177 & $16.3 \%$ \\
\hline IV & 4 & 6.5 & 14767 & 2448 & $6.0(1.7-21.5)$ & 12318 & 80 & $7.4 \%$ \\
\hline
\end{tabular}

${ }^{\mathrm{a}}$ The ratio of costs per patient-year to costs per person-year in general population

${ }^{b}$ The difference between costs per patient-year and costs per person-year in general population

The first year after CMM diagnosis, the average health care cost of CMM patients was 2.8 times higher than that of the general population and the CMM-related cost per patient was $€ 5348$ (Table 8). The CMM-related costs increased with age except for patients 80 years or older. After adjustment for clinical stage, the CMM-related costs varied little between age groups, but costs among patients 80 years or older were still lower. Without adjustment for clinical stage, men had a slightly higher average CMMrelated cost than women. The gender difference was reduced after adjusting for clinical stage, and it disappeared when the oldest group ( $>80$ years) was excluded. 
Table 8. Direct healthcare costs in 1075 patients with cutaneous malignant melanoma (CMM) the first year after diagnosis by age and gender in County of Östergötland, Sweden 2005-2012.

\begin{tabular}{|c|c|c|c|c|c|c|c|}
\hline Category & $\begin{array}{l}\text { Number } \\
\text { of } \\
\text { CMM } \\
\text { patients }\end{array}$ & $\begin{array}{l}\text { Number } \\
\text { of } \\
\text { patient- } \\
\text { years }\end{array}$ & $\begin{array}{l}\text { Costs } \\
\text { per } \\
\text { patient- } \\
\text { year }(€)\end{array}$ & $\begin{array}{l}\text { Costs per } \\
\text { person- } \\
\text { year in } \\
\text { general } \\
\text { population } \\
(€)\end{array}$ & $\begin{array}{l}\text { Healthcare } \\
\text { cost ratio } \\
(95 \% \mathrm{CI})^{\mathrm{a}}\end{array}$ & $\begin{array}{l}\text { CMM- } \\
\text { related } \\
\text { costs } \\
(€) \text { per } \\
\text { patient- } \\
\text { year }^{\text {b }}\end{array}$ & $\begin{array}{l}\text { Stage- } \\
\text { adjusted } \\
\text { CMM- } \\
\text { related } \\
\text { costs }(€) \\
\text { per } \\
\text { patient- }\end{array}$ \\
\hline All patients & 1075 & 970.1 & 8390 & 3042 & $2.8(2.6-3.0)$ & 5348 & - \\
\hline \multicolumn{8}{|l|}{ Age } \\
\hline $0-39$ & 126 & 116.3 & 6214 & 1352 & $4.6(3.5-6.1)$ & 4861 & 6059 \\
\hline $40-54$ & 324 & 301.7 & 6632 & 1579 & $4.2(3.6-4.9)$ & 5053 & 5573 \\
\hline $55-69$ & 252 & 225.7 & 8514 & 2721 & $3.1(2.7-3.7)$ & 5793 & 5771 \\
\hline $70-79$ & 207 & 186.2 & 10328 & 4282 & $2.4(2.0-2.9)$ & 6046 & 6077 \\
\hline $80+$ & 166 & 140.3 & 11204 & 6123 & $1.8(1.6-2.1)$ & 5081 & 4476 \\
\hline \multicolumn{8}{|l|}{ Gender } \\
\hline Men & 535 & 478.6 & 8854 & 3285 & $2.7(2.4-3.0)$ & 5569 & 5587 \\
\hline Women & 540 & 491.5 & 7938 & 2802 & $2.8(2.5-3.2)$ & 5137 & 5288 \\
\hline \multicolumn{8}{|c|}{ Gender $<80$ years } \\
\hline Men & 453 & 412.7 & 8180 & 2672 & $3.1(2.7-3.5)$ & 5508 & 5429 \\
\hline Women & 456 & 417.2 & 7652 & 2289 & $3.3(2.9-3.8)$ & 5363 & 5513 \\
\hline
\end{tabular}

\footnotetext{
${ }^{\mathrm{a}}$ The ratio of costs per patient-year to costs per person-year in general population

${ }^{b}$ The difference between costs per patient-year and costs per person-year in general population
} 


\section{DISCUSSION}

\section{Paper I}

In the present Swedish, nationwide study including over 30000 patients diagnosed with a first primary invasive CMM, the most important finding is a shift over time towards thinner tumours for men accompanied by an improved survival. This trend was seen in both younger and older men. The proportion of T1 CMM among women was higher than for men but quite stable over time. Men showed more T3 and T4 CMMs. These gender differences may partly be attributed to better skin selfexamination practices and health related behaviours in women resulting in thinner, potentially curable tumours. The improvement seen for men may have several reasons. There have been no directed skin cancer awareness campaigns towards men in Sweden, instead one may speculate that men became more concerned with their health in general leading to change in their care seeking behaviour.

Recent data from Holland show similar proportions of T1 CMMs as in Sweden and the gender difference for younger age groups in Holland is consistent with present SMR data (22). Regarding survival trends in Holland, the prognosis in men improved more than in women when comparing 2004-2008 with 1999-2003 (29).

Women have a superior 5-year CMM-specific survival compared to men. This difference is mainly due to behavioural factors with women diagnosed earlier, resulting in a lower proportion of T3 and T4 CMM compared to men. Biological sex differences may also to some extent contribute to disparities in survival $(55,56)$. The 5 -year CMM-specific survival in younger women is now above 95\% leaving little room for further large improvements. Early detection measures directed to men and older women may improve their survival in a more substantial way.

\section{Paper II}

Using SMR data, we identified three prognostic groups; a low risk group (67.9\% of T1 cases), an intermediate risk group ( $28.6 \%$ of $\mathrm{T} 1$ cases), and a high risk group (3.5\% of T1 cases). The latter has a slightly higher mortality rate than T2a tumours in a national report from the SMR, 1990-2008 (57). 
The 10-year CMM-specific mortality rates for T1 CMM where much lower in SMR compared to the high mortality rates found in compiled institutional based materials such as reported in the AJCC 2002 (13, 14) and AJCC 2009 (6). Other population-based materials such as the Queensland Cancer Registry (34) and data from the Surveillance, Epidemiology, and End Results Program (SEER) $(21,35)$ showed death rates similar to SMR. Gimotty et al. validated the AJCC 2002 classification and found that it was suitable for constructing stages, but was imperfectly calibrated to the US population, since the survival rates in the AJCC material were much lower than in the US population (35). It is reasonable to speculate that large specialised institutions contributing to the AJCC database have a higher proportion of patients with poor prognosis since patients with T1 CMM and recurrence are referred to those institutions for further treatment.

SMR data indicate that the original thickness cut off value $(0.76 \mathrm{~mm})$ defined by Breslow (15) still seems to have a significant impact on the prognosis of T1 CMM. Clark et al. (58) demonstrated that almost all CMMs $\leq 0.75 \mathrm{~mm}$ or of Clark level II were of radial growth phase and that these CMMs rarely showed mitoses. They found no metastases in that group compared with CMMs with a vertical growth phase.

It is important to have good data in order to give patients with T1 CMM more accurate prognostic information based on tumour thickness, Clark's level of invasion and ulceration. In Sweden T1 CMMs constitute more than 50\% (even higher for females and younger patients) of all CMMs. The prognosis is generally very good compared to other stages of CMM. We found, however, a mortality range of $1-25 \%$, showing the importance of using prognostic factors. In the SMR, the high risk group (3.5\% of T1) accounts for $15 \%$ of all T1 CMM deaths, and the intermediate group (28.6\% of T1) accounts for 51\% of all T1 CMM deaths.

\section{Paper III}

In this large Swedish, nationwide population-based setting with more than 27000 patients, we demonstrate that CMM-specific survival was significantly reduced for patients with low education. This lower CMM-specific survival rate among less 
educated individuals was mainly explained by a more advanced clinical stage of CMM at diagnosis.

Our finding that low SES as measured by level of education is associated with a worse outcome is supported by previous studies of varying design (40-44, 46-48). In Sweden, the tax-funded national health care system aims to provide care on equal terms to all citizens. National guidelines for CMM diagnosis, treatment and follow-up have been implemented to minimise variation in the primary management. Despite this, in the present study, patients with lower education had more advanced disease at diagnosis, corroborating previous studies (40, 41, 44, 46, 47, 59-61). This finding explains in part the lower CMM-specific survival among low-educated groups in the Swedish setting. Investigating the links between low SES and CMM, previous studies have found that individuals with lower SES might receive their diagnoses at later stages as a result of lower awareness of early warning-signs, fewer physician skin examinations (PSE) and skin self-examinations as well as reduced perception of the risks of CMM $(60,61)$. There are several possible mechanisms by which education may have an impact on health status. For example, persons with higher education may have acquired better health-related knowledge as well as skills in navigating and interacting effectively within the healthcare system. (62)

After adjusting for clinical stage at diagnosis and for other prognostic factors, patients with low education still had a13\% higher risk of CMM death compared to patients with high education. A limitation is that SMR did not include information on sentinel node biopsy and mitotic rate as these variables were successively implemented and registered in Sweden during the study period. Inequalities in treatment intensity in patients with different SES have been found for other cancers in Sweden $(63,64)$. It is unlikely, however, that this has influenced our results since, during the study period no treatment, apart from early primary surgery, has been shown to impact survival in CMM. We could not clearly demonstrate a clinically important difference from time of primary surgical management to the secondary excision in relation to educational level among patients with stage I and II CMM (III). 


\section{Paper IV}

The first year after CMM diagnosis, the average costs for all CMM patients were nearly three times higher compared to the general population. This finding is similar to a recent study from Denmark where CMM patients had twice as high direct annual costs compared to a control group (65).

After adjusting for clinical stage, CMM-related costs per patient-year where similar across age categories except for patients 80 years or older. This might be an effect of less intensive treatment for the oldest patients. The unadjusted CMM-related costs were slightly higher for men compared to women, but the difference disappeared after adjusting for clinical stage and excluding patients over 80 years.

The healthcare cost ratios decreased over time, partly as a result of the lower survival of costly patients with advanced stage III-IV while surviving patients were relatively healthier. Patients in clinical stage I with little risk for metastases showed almost the same healthcare costs as the general population.

Under the study period, no good treatment existed for patients with metastatic disease. In the last few years, new medications for systemic treatment have been accepted in Sweden. This will lead to increased costs mainly for clinical stage III and IV patients.

The direct healthcare costs for CMM patients were significantly higher than for the general population, independent of clinical stage. CMM patients diagnosed in clinical stage III-IV were associated with particularly high costs and the healthcare system may save resources by finding CMM patients in earlier stages. 


\section{CONCLUSIONS}

\section{Paper I}

For men, there has been a shift over time towards thinner tumours at diagnosis

accompanied by an improved survival. Women are still diagnosed with considerably thinner tumours and they experience a better survival than men.

\section{Paper II}

Tumour ulceration, tumour thickness and Clark's level of invasion all showed significant independent long-term prognostic information in T1 CMMs. By combining these factors, three distinct prognostic subgroups were identified.

\section{Paper III}

Lower level of education was associated with reduced CMM-specific survival, which may at least partially be attributed to a more advanced stage at diagnosis.

\section{Paper IV}

The direct healthcare costs for CMM patients were significantly higher than for the general population, independent of clinical stage. CMM patients diagnosed in clinical stage III-IV were associated with particularly high costs. 


\section{IMPLICATIONS AND FUTURE PERSPECTIVES}

Even though the survival among Swedish patients with CMM is among the highest in the world and still seems to improve, the results of this thesis emphasise the need of improved early detection strategies. This may be of particular concern in men, older women, and groups with a low level of education. The results also imply that the costs for the management of CMM patients may be reduced if early detection efforts are successful and lead to a more favourable stage distribution. More work has to be done in order to find potential patients earlier. For young men, especially with low level of education, information about CMM and how they can come in contact with a doctor is important.

PSE and SSE with good education could be directed to risk groups. A recent review showed that full-body PSE was associated with thinner tumours, especially in men above 60 years of age. The same review showed that SSE with some training resulted in the respondents becoming good at detecting atypical moles with a sensitivity and specificity of $90 \%$ and $72 \%$, respectively (66). Further, one can speculate in the importance to educate non-clinicians in occupations with close contact to persons' skin about the appearance of typical CMMs. A recent review from USA showed a very high interest of skin cancer detection among hair-dressers and chiropractors (66).

The SMR contains information on tumour thickness for more than $95 \%$ of all CMM patients diagnosed in Sweden since 1997, which is unique compared to other similar registers in the world. SMR is very useful when looking at trends in T-category over time. SMR is also easily linked to the CDR making it possible to perform survival analysis and to find prognostic factors. However, there are several potential improvements. For instance SMR lacks information about the occurrence of metastasised disease and whether the patients had undergone systemic treatment or advanced surgery.

SMR contain several histopathological variables such as histogenetic type, tumour ulceration, Clark's level of invasion, and tumour regression. The finding of a better 
risk stratification of thin CMMs using some of these factors may help to improve the management of this large patient group. SMR contains information on mitotic rate from 2009. This data will in the future be analysed against long-term mortality in order to determine whether adding mitotic rate as a prognostic factor can further improve risk stratification for patients diagnosed with T1 CMM. 


\section{SVENSK SAMMANFATTNING}

Antalet patienter som drabbas av malignt melanom i huden ökar dramatiskt i Sverige och har så gjort under lång tid. De flesta patienter söker vård i tidigt skede med tunna melanom som följd. I Sverige överlever nio av tio patienter sin sjukdom men prognosen för en enskild patient är starkt beroende av hur länge hudförändringen har funnits samt hur tjock den har blivit. Den primära behandlingen är kirurgi och de flesta patienter blir botade $\mathrm{i}$ och med detta ingrepp. Om patienten har fått spridd sjukdom är sannolikheten att bli botad låg, även om nya mediciner med viss effekt på tumörbördan har kommit de senaste åren. Syftet med avhandlingen är att, med hjälp av bland annat det svenska kvalitetsregistret för hudmelanom, öka kunskapen om tidstrender när det gäller tumörtjocklek och överlevnad (studie I), faktorer som påverkar prognosen för patienter med tunna melanom (studie II), hur utbildningsgrad påverkar stadium vid diagnos och prognos (studie III), samt vårdkostnader för melanompatienter i olika stadier (studie IV).

Avhandlingen visar att både andelen tunna melanom och överlevnaden bland män har ökat från perioden 1997-2001 till 2007-2011. Kvinnor har dock fortfarande tunnare melanom och bättre överlevnad. Patienter som är 65 år eller äldre har betydligt tjockare melanom än de som är yngre än 65 år, och för de äldre patienterna är skillnaden mellan män och kvinnor mindre uttalad. Patienter med lägre utbildningsnivå (både män och kvinnor) har vid diagnos tjockare melanom och sämre överlevnad än de som är högutbildade. Den fjärde studien visar att vårdkostnaden är betydligt högre för patienter som diagnostiserats i ett sent sjukdomsstadium. Bland patienter med tunna melanom har en mindre högriskgrupp och en stor grupp med mycket låg risk att dö av sin sjukdom identifierats. Detta åstadkoms genom att kombinera flera olika tumörfaktorer.

Även om prognosen för svenska melanompatienter är mycket god, sett ur ett internationellt perspektiv, visar resultaten av avhandlingen att det även i Sverige finns ett behov av att kunna diagnostisera fler i ett tidigare skede av sjukdomen. Detta gäller speciellt män, äldre kvinnor och grupper med låg utbildning. Genom att öka andelen 
patienter som upptäcks i ett tidigt skede kan överlevnaden förbättras. Dessutom skulle sjukvårdens kostnader förmodligen minska. 


\section{ACKNOWLEDGEMENTS}

John Carstensen, my supervisor, for being an excellent tutor and for giving me the energy to fulfil the hard work completing this thesis.

Christer Lindholm, my co-supervisor, for introducing me into the world of melanoma and for always having time for all my questions.

Hans Starkhammar, my boss and co-supervisor, for giving me the opportunity to be a PHD student and for always supporting me in my work.

The members of the SMR steering committee and members of SMSG, for good discussions and for great help with papers I-III.

All my co-authors, for taking time reading the papers resulting in many improvements. My friends and colleagues at RCC south east, for showing interest and support in my work.

Hanna Eriksson, Johan Hansson, Eva Månsson-Brahme and Margareta FrohmNilsson, for a great collaboration with the socioeconomic project and for letting me use paper III in my PHD thesis.

My wonderful wife Ida and our sweet daughters Sigrid and Alva, for showing me that life is much more than numbers. 


\section{REFERENCES}

1. Cancer Incidence in Sweden 2012. National Board of Health and Welfare, Stockholm, Sweden. 2013.

2. Nationell kvalitetsrapport för diagnosår 2014 från Nationella hudmelanomregistret. http://www.cancercentrum.se/PageFiles/546/20140929_Melanom_Rapport_20102013.pdf. 2014.

3. Tucker MA, Goldstein AM. Melanoma etiology: where are we? Oncogene. 2003 May 19;22(20):3042-52.

4. Leachman SA, Carucci J, Kohlmann W, Banks KC, Asgari MM, Bergman W, et al. Selection criteria for genetic assessment of patients with familial melanoma. J Am Acad Dermatol. 2009 Oct;61(4):677 e1-14.

5. De Angelis R, Sant M, Coleman MP, Francisci S, Baili P, Pierannunzio D, et al. Cancer survival in Europe 1999-2007 by country and age: results of EUROCARE-5-a population-based study. Lancet Oncol. 2013 Dec 4.

6. Balch CM, Gershenwald JE, Soong SJ, Thompson JF, Atkins MB, Byrd DR, et al. Final Version of 2009 AJCC Melanoma Staging and Classification. J Clin Oncol. 2009;27(36):6199-206.

7. Menzies AM, Long GV. Systemic treatment for BRAF-mutant melanoma: where do we go next? Lancet Oncol. 2014;15(9):70072-5.

8. Lo JA, Fisher DE. The melanoma revolution: from UV carcinogenesis to a new era in therapeutics. Science. 2014 Nov 21;346(6212):945-9.

9. Paoli J, Danielsson M, Wennberg AM. Results of the 'Euromelanoma Day' screening campaign in Sweden 2008. J Eur Acad Dermatol Venereol. 2009 Nov;23(11):1304-10.

10. Hamidi R, Cockburn MG, Peng DH. Prevalence and predictors of skin selfexamination: prospects for melanoma prevention and early detection. Int J Dermatol. 2008 Oct;47(10):993-1003.

11. Kasparian NA, Branstrom R, Chang YM, Affleck P, Aspinwall LG, Tibben A, et al. Skin examination behavior: the role of melanoma history, skin type, psychosocial factors, and region of residence in determining clinical and self-conducted skin examination. Arch Dermatol. 2012 Oct;148(10):1142-51. 
12. Ludvigsson JF, Otterblad-Olausson P, Pettersson BU, Ekbom A. The Swedish personal identity number: possibilities and pitfalls in healthcare and medical research. Eur J Epidemiol. 2009;24(11):659-67.

13. Balch CM, Soong SJ, Gershenwald JE, Thompson JF, Reintgen DS, Cascinelli N, et al. Prognostic factors analysis of 17,600 melanoma patients: Validation of the American Joint Committee on Cancer melanoma staging system. J Clin Oncol. 2001;19(16):3622-34.

14. Balch CM, Buzaid AC, Soong SJ, Atkins MB, Cascinelli N, Coit DG, et al. Final version of the American Joint Committee on Cancer staging system for cutaneous melanoma. J Clin Oncol. 2001;19(16):3635-48.

15. Breslow A. Thickness, cross-sectional areas and depth of invasion in the prognosis of cutaneous melanoma. Ann Surg. 1970 Nov;172(5):902-8.

16. Eriksson H, Frohm-Nilsson M, Hedblad MA, Hellborg H, Kanter-Lewensohn L, Krawiec K, et al. Interobserver variability of histopathological prognostic parameters in cutaneous malignant melanoma: impact on patient management. Acta Derm Venereol. 2013 Jul 6;93(4):411-6.

17. Lindholm C, Andersson R, Dufmats M, Hansson J, Ingvar C, Moller T, et al. Invasive cutaneous malignant melanoma in Sweden, 1990-1999 - A prospective, populationbased study of survival and prognostic factors. Cancer-Am Cancer Soc. 2004;101(9):2067-78.

18. Clark WH, Jr., From L, Bernardino EA, Mihm MC. The histogenesis and biologic behavior of primary human malignant melanomas of the skin. Cancer Res. 1969;29(3):705-27.

19. Mayer JE, Swetter SM, Fu T, Geller AC. Screening, early detection, education, and trends for melanoma: Current status (2007-2013) and future directions: Part I. Epidemiology, high-risk groups, clinical strategies, and diagnostic technology. J Am Acad Dermatol. 2014 Oct;71(4):599 e1- e12.

20. Mar V, Roberts H, Wolfe R, English DR, Kelly JW. Nodular melanoma: a distinct clinical entity and the largest contributor to melanoma deaths in Victoria, Australia. J Am Acad Dermatol. 2013 Apr;68(4):568-75. 
21. Gimotty PA, Elder DE, Fraker DL, Botbyl J, Sellers K, Elenitsas R, et al. Identification of high-risk patients among those diagnosed with thin cutaneous melanomas. J Clin Oncol. 2007;25(9):1129-34.

22. Kruijff S, Bastiaannet E, Francken AB, Schaapveld M, van der Aa M, Hoekstra HJ. Breslow thickness in the Netherlands: a population-based study of 40880 patients comparing young and elderly patients. Br J Cancer. 2012 Jul 24;107(3):570-4.

23. Wirehn AB, Andersson A, Ostgren CJ, Carstensen J. Age-specific direct healthcare costs attributable to diabetes in a Swedish population: a register-based analysis. Diabet Med. 2008;25(6):732-7.

24. Erdmann F, Lortet-Tieulent J, Schuz J, Zeeb H, Greinert R, Breitbart EW, et al. International trends in the incidence of malignant melanoma 1953-2008-are recent generations at higher or lower risk? Int J Cancer. 2013 Jan 15;132(2):385-400.

25. Mansson-Brahme E, Johansson H, Larsson O, Rutqvist LE, Ringborg U. Trends in incidence of cutaneous malignant melanoma in a Swedish population 1976-1994. Acta Oncol. 2002;41(2):138-46.

26. Thorn M, Ponten F, Bergstrom R, Sparen P, Adami HO. Trends in tumour characteristics and survival of malignant melanoma 1960-84: a population-based study in Sweden. Br J Cancer. 1994 Oct;70(4):743-8.

27. Cancer survival and prevalence in Australia: period estimates from 1982 to 2010. Asia Pac J Clin Oncol. 2013;9(1):29-39.

28. Shaikh WR, Xiong M, Weinstock MA. The contribution of nodular subtype to melanoma mortality in the United States, 1978 to 2007. Arch Dermatol. 2012;148(1):30-6.

29. Hollestein LM, van den Akker SA, Nijsten T, Karim-Kos HE, Coebergh JW, de Vries E. Trends of cutaneous melanoma in The Netherlands: increasing incidence rates among all Breslow thickness categories and rising mortality rates since 1989. Ann Oncol. 2012 Feb;23(2):524-30.

30. MacKie RM, Bray C, Vestey J, Doherty V, Evans A, Thomson D, et al. Melanoma incidence and mortality in Scotland 1979-2003. Brit J Cancer. 2007 Jun 4;96(11):1772-7. 
31. Tryggvadottir L, Gislum M, Hakulinen T, Klint A, Engholm G, Storm HH, et al. Trends in the survival of patients diagnosed with malignant melanoma of the skin in the Nordic countries 1964-2003 followed up to the end of 2006. Acta Oncol. 2010 Jun;49(5):665-72.

32. Elder DE. Thin melanoma. Arch Pathol Lab Med. 2011 Mar;135(3):342-6.

33. Gimotty PA, Guerry D. Prognostication in Thin Cutaneous Melanomas. Arch Pathol Lab Med. 2010;134(12):1758-63.

34. Green AC, Baade P, Coory M, Aitken JF, Smithers M. Population-based 20-year survival among people diagnosed with thin melanomas in Queensland, Australia. J Clin Oncol. 2012;30(13):1462-7.

35. Gimotty PA, Botbyl J, Soong SJ, Guerry D. A population-based validation of the American Joint Committee on Cancer melanoma staging system. J Clin Oncol. 2005;23(31):8065-75.

36. Leiter U, Buettner PG, Eigentler TK, Garbe C. Prognostic factors of thin cutaneous melanoma: An analysis of the central malignant melanoma registry of the German dermatological society. J Clin Oncol. 2004;22(18):3660-7.

37. Eigentler TK, Buettner PG, Leiter U, Garbe C. Impact of ulceration in stages I to III cutaneous melanoma as staged by the American Joint Committee on Cancer staging system: An analysis of the German Central Malignant Melanoma Registry. J Clin Oncol. 2004;22(21):4376-83.

38. McKinnon JG, Yu XO, McCarthy WH, Thompson JF. Prognosis for patients with thin cutaneous melanoma - Long-term survival data from the New South Wales Central Cancer Registry and the Sydney Melanoma Unit. Cancer-Am Cancer Soc. 2003;98(6):1223-31.

39. Singh SD, Ajani UA, Johnson CJ, Roland KB, Eide M, Jemal A, et al. Association of cutaneous melanoma incidence with area-based socioeconomic indicators-United States, 2004-2006. J Am Acad Dermatol. 2011 Nov;65(5 Suppl 1):S58-68.

40. Mandala M, Imberti GL, Piazzalunga D, Belfiglio M, Lucisano G, Labianca R, et al. Association of Socioeconomic Status With Breslow Thickness and Disease-Free and Overall Survival in Stage I-II Primary Cutaneous Melanoma. Mayo Clin Proc. 2011 Feb;86(2):113-9. 
41. Linos E, Swetter SM, Cockburn MG, Colditz GA, Clarke CA. Increasing burden of melanoma in the United States. J Invest Dermatol. 2009 Jul;129(7):1666-74.

42. Hussain SK, Lenner P, Sundquist J, Hemminki K. Influence of education level on cancer survival in Sweden. Ann Oncol. 2008 Jan;19(1):156-62.

43. Birch-Johansen F, Hvilsom G, Kjaer T, Storm H. Social inequality and incidence of and survival from malignant melanoma in a population-based study in Denmark, 19942003. Eur J Cancer. 2008 Sep;44(14):2043-9.

44. Reyes-Ortiz CA, Goodwin JS, Freeman JL, Kuo YF. Socioeconomic status and survival in older patients with melanoma. J Am Geriatr Soc. 2006 Nov;54(11):175864.

45. Downing A, Newton-Bishop JA, Forman D. Recent trends in cutaneous malignant melanoma in the Yorkshire region of England; incidence, mortality and survival in relation to stage of disease, 1993-2003. Brit J Cancer. 2006 Jul 3;95(1):91-5.

46. Chang AE, Karnell LH, Menck HR. The National Cancer Data Base report on cutaneous and noncutaneous melanoma: a summary of 84,836 cases from the past decade. The American College of Surgeons Commission on Cancer and the American Cancer Society. Cancer-Am Cancer Soc. 1998 Oct 15;83(8):1664-78.

47. MacKie RM, Hole DJ. Incidence and thickness of primary tumours and survival of patients with cutaneous malignant melanoma in relation to socioeconomic status. BMJ. 1996 May 4;312(7039):1125-8.

48. Vagero D, Persson G. Risks, survival and trends of malignant melanoma among white and blue collar workers in Sweden. Soc Sci Med. 1984;19(4):475-8.

49. Eriksson H, Lyth J, Mansson-Brahme E, Frohm-Nilsson M, Ingvar C, Lindholm C, et al. Later stage at diagnosis and worse survival in cutaneous malignant melanoma among men living alone: a nationwide population-based study from sweden. J Clin Oncol. 2014 May 1;32(13):1356-64.

50. Alexandrescu DT. Melanoma costs: a dynamic model comparing estimated overall costs of various clinical stages. Dermatol Online J. 2009;15(11):1.

51. Seidler AM, Pennie ML, Veledar E, Culler SD, Chen SC. Economic burden of melanoma in the elderly population: population-based analysis of the Surveillance, 
Epidemiology, and End Results (SEER)--Medicare data. Arch Dermatol. 2010 Mar;146(3):249-56.

52. Tsao H, Rogers GS, Sober AJ. An estimate of the annual direct cost of treating cutaneous melanoma. J Am Acad Dermatol. 1998;38(5):669-80.

53. Kirkwood BR, Sterne JAC. Essential medical statistics. 2nd ed. Malden, MA: Blackwell Science; 2003.

54. Kaplan EL, Meier P. Nonparametric Estimation from Incomplete Observations. J Am Stat Assoc. 1958;53(282):457-81.

55. Gamba CS, Clarke CA, Keegan TH, Tao L, Swetter SM. Melanoma survival disadvantage in young, non-Hispanic white males compared with females. JAMA Dermatol. 2013 Aug;149(8):912-20.

56. Joosse A, Collette S, Suciu S, Nijsten T, Lejeune F, Kleeberg UR, et al. Superior outcome of women with stage I/II cutaneous melanoma: pooled analysis of four European Organisation for Research and Treatment of Cancer phase III trials. J Clin Oncol. 2012 Jun 20;30(18):2240-7.

57. The Swedish Melanoma Register (SMR) in Sweden 1990-2008. http://www.cancercentrum.se/Global/Diagnoser/hudmelanom/rapporter/Melanom_Nat KvalReg1990-2008.pdf page 22, figure 12.

58. Clark WH, Elder DE, Guerry D, Braitman LE, Trock BJ, Schultz D, et al. Model Predicting Survival in Stage-I Melanoma Based on Tumor Progression. J Natl Cancer I. 1989;81(24):1893-904.

59. Baumert J, Plewig G, Volkenandt M, Schmid-Wendtner MH. Factors associated with a high tumour thickness in patients with melanoma. $\mathrm{Br}$ J Dermatol. 2007 May;156(5):938-44.

60. Pollitt RA, Clarke CA, Shema SJ, Swetter SM. California medicaid Enrollment and melanoma stage at diagnosis - A population-based study. Am J Prev Med. 2008 Jul;35(1):7-13.

61. Youl PH, Baade PD, Parekh S, English D, Elwood M, Aitken JF. Association between melanoma thickness, clinical skin examination and socioeconomic status: results of a large population-based study. Int J Cancer. 2011 May 1;128(9):2158-65. 
62. Pollitt RA, Swetter SM, Johnson TM, Patil P, Geller AC. Examining the pathways linking lower socioeconomic status and advanced melanoma. Cancer-Am Cancer Soc. 2012 Aug 15;118(16):4004-13.

63. Berglund A, Holmberg L, Tishelman C, Wagenius G, Eaker S, Lambe M. Social inequalities in non-small cell lung cancer management and survival: a populationbased study in central Sweden. Thorax. 2010 Apr;65(4):327-33.

64. Cavalli-Bjorkman N, Lambe M, Eaker S, Sandin F, Glimelius B. Differences according to educational level in the management and survival of colorectal cancer in Sweden. Eur J Cancer. 2011 Jun;47(9):1398-406.

65. Bentzen J, Kjellberg J, Thorgaard C, Engholm G, Phillip A, Storm HH. Costs of illness for melanoma and nonmelanoma skin cancer in Denmark. Eur J Cancer Prev. 2013 Nov;22(6):569-76.

66. Mayer JE, Swetter SM, Fu T, Geller AC. Screening, early detection, education, and trends for melanoma: Current status (2007-2013) and future directions: Part II. Screening, education, and future directions. J Am Acad Dermatol. 2014 Oct;71(4):611 e1- e10. 



\section{Papers}

The articles associated with this thesis have been removed for copyright reasons. For more details about these see:

http://urn.kb.se/resolve?urn=urn:nbn:se:liu:diva-113145 